\title{
DIVERSITY AND DISTRIBUTION OF THE MOUSE OPOSSUMS OF THE GENUS THYLAMYS (DIDELPHIMORPHIA, DIDELPHIDAE) IN NORTH- EASTERN AND CENTRAL ARGENTINA
}

\author{
DIVERSIDAD Y DISTRIBUCION DE LAS MARMOSAS DEL GENERO \\ THYLAMYS (DIDELPHIMORPHIA, DIDELPHIDAE) EN EL NORESTE Y \\ CENTRO DE ARGENTINA
}

\author{
Pablo Teta ${ }^{1 *}$, Guillermo D’Elía ${ }^{2}$, David Flores ${ }^{1} \&$ Noé de La Sancha ${ }^{3}$ \\ ${ }^{1}$ Museo Argentino de Ciencias Naturales "Bernardino Rivadavia”, Avenida Angel Gallardo 470 (C1405DJR) Buenos \\ Aires, Argentina. \\ ${ }^{2}$ Departamento de Zoología, Universidad de Concepción, casilla 160-C, Concepción, Chile. \\ ${ }^{3}$ Department of Biological Sciences, Texas Tech University, P.O. Box 43131, Lubbock, Texas, USA. \\ E-mail: antheca@yahoo.com.ar
}

\begin{abstract}
Phylogenetic analysis of a fragment of the mitochondrial genome and qualitative and quantitative assessments of morphological variation suggest that, in its current conception, Thylamys pusillus (Desmarest, 1804) is a complex of at least three species. In the taxonomic arrangement proposed in this work, the populations in the Argentinean provinces of Entre Ríos and Corrientes are here referred to T. citellus (Thomas, 1912), while the small Thylamys that lives in the Argentinean Dry Chaco are provisionally referred to T. pulchellus (Cabrera, 1934). In our scheme, Thylamys pusillus is restricted to the Bolivian and Paraguayan Chaco and the vicinities of northern Formosa province in Argentina. We provide emended diagnosis for T. citellus and T. pulchellus, together with detailed morphological descriptions and discuss their distinctiveness from other species of Thylamys. In addition, we included new distributional data.
\end{abstract}

KEYWORDS: Argentina, mouse opossum, species limits, taxonomy.

\section{RESUMEN}

El análisis filogenético de un fragmento del genoma y el estudio cualitativo y cuantitativo de la morfología externa y craneana sugiere que, en su actual acepción, Thylamys pusillus (Desmarest, 1804) es un complejo de por lo menos tres especies. En el arreglo taxonómico propuesto en este trabajo, las poblaciones en las provincias argentinas de Entre Ríos y Corrientes son referidas como T. citellus (Thomas, 1912), mientras que una forma pequeña de Thylamys que habita en el Chaco Seco de Argentina es provisoriamente referida como T. pulchellus (Cabrera, 1934). En este esquema, la distribución de Thylamys pusillus es restringida al Chaco de Bolivia, Paraguay y áreas adyacentes de Argentina en el nordeste de la provincia de Formosa. Se proveen diagnosis enmendadas para T. citellus y T. pulchellus, conjuntamente con una detallada descripción morfológica de ambas entidades y una discusión de las diferencias con otras especies de Thylamys. Por ultimo, se incluyen nuevos datos de distribución.

Palabras clave: Argentina, marmosas, límite de especies, taxonomía. 


\section{INTRODUCTION}

The genus Thylamys Gray 1843 comprises small mouse opossums with some distinctive traits, including a characteristic tricolor fur pattern, capacity to store fat in the tail, uniformly narrow nasals with subparallel lateral margins, large posterolateral palatal foramina extending anteriorly between M4 protocones, and other morphological characters in body proportions, skull, dentition, and postcranium (Creigthon \& Gradner 2008, Flores 2009, Voss \& Jansa 2009). Unlike most other South American mouse opossums, which are found in tropical or subtropical moist forests, Thylamys principally inhabits semi-arid and open areas and occurs at temperate latitudes (Flores et al. 2007, Creighton \& Gardner 2008).

Thylamys has been under taxonomic revision since Tate (1933) recognized the elegans species group as part of the genus Marmosa. Subsequent systematic works, based on morphological, serological, and chromosomal evidence confirmed the distinctiveness of Thylamys within the didelphid radiation (Reig et al. 1987, Gardner \& Creighton 1989, Palma et al. 2002). Phylogenetic studies based on genetic data confirmed the monophyly of the genus, and elucidated some basic questions regarding relationships among its species and their limits (Kirsch \& Palma 1995, Jansa \& Voss 2000, Palma \& Yates 1998, Flores et al. 2000, Meynard et al. 2002, Palma et al. 2002, Braun et al. 2005a).

As currently recognized, Thylamys comprises at least nine species (Creighton \& Gardner 2008, with modifications according to Braun et al. 2005a). In northern Argentina, this is the most diverse marsupial genus, and one of the groups with more taxonomic uncertainties. For many years, taxonomists considered only three species in northern Argentina: T. pallidior, in arid highlands and montane deserts; $T$. venustus in montane humid and transitional forests; and T. pusillus in the extensive xerophytic shrubs and grasslands from the north and northeastern regions of the country.

The taxonomic status of Thylamys pusillus has long been controversial. For instance, Tate (1933) restricted the name pusillus to populations in northeastern Argentina and eastern Paraguay. Later, Cabrera (1958) expanded pusillus to include forms from the Andean highlands and southern steppes previously assigned to pallidior by Tate (1933). Recent contributions (e.g. Solari 2003, Braun et al. 2005a, Flores et al. 2007, Creighton \& Gardner 2008) restrict the name pusillus to the central and northeastern populations from Argentina, western Paraguay and eastern Bolivia. Under this conception, T. pusillus includes, as subjective junior synonyms, the nominal taxa Marmosa citella Thomas, 1912; Marmosa janetta pulchella Cabrera, 1934; and Marmosa verax Thomas, 1921 (see Creighton \& Gardner 2008). Part of the confusion regarding the biological and geographic limits of T. pusillus derives from the absence of a type specimen. In fact, the name pusillus was proposed on the basis of Azara's description of the "micouré nain" or "enano" (Azara, 1801, 1802), without the formal designation of a type specimen. Given this, Voss et al. (in press) designed a neotype for pusillus from Trans-Chaco Highway, $460 \mathrm{~km}$ NW of Villa Hayes (Departamento Boquerón, Paraguay). In the same contribution, the authors suggest that some Argentinean populations of pusillus-like Thylamys may represent a different species than the nominotypical form that occurs in Paraguay and eastern Bolivia. On the other hand, Argentinean populations from Entre Ríos and Corrientes provinces (Mesopotamia), usually synonymyzed in the literature with pusillus, have a long and complex taxonomic history, being alternatively included in Marmosa marmota, Thylamys pusillus, or considered a separated species under the name of M. citella (Thomas, 1912).

In this work, we present a taxonomic analysis of Argentinean populations of Thylamys that are currently included within T. pusillus. The main goal of this study is to clarify how many species inhabit the area. To do so, we analyzed morphologic and genetic evidence. In light of our results, we provide emended diagnosis, re-descriptions, and comparisons for the species recognized in a new taxonomic arrangement herein proposed.

\section{MATERIALS AND METHODS}

Study specimens. A total of 86 specimens from Argentina and Paraguay were studied (Fig. 1, Appendix 1); these were already housed in systematic collections, or were obtained by us either by trapping or from owl pellet analysis (Appendix 1). Animal care and use procedures and guidelines approved by the American Society of Mammalogists were followed (Gannon et al. 2007). For comparative purposes we studied series 


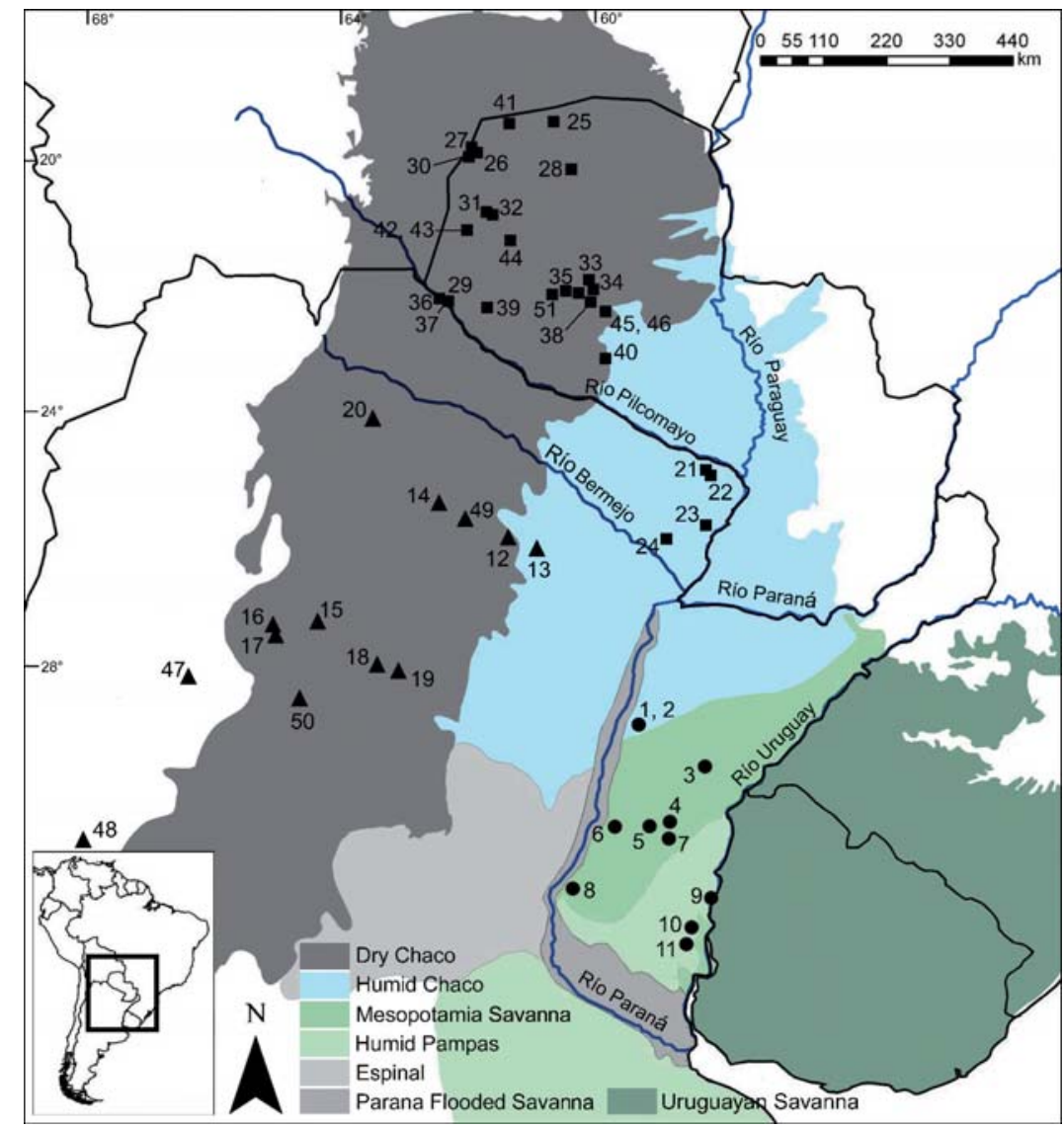

FIGURE 1. Recording localities for the specimens of Thylamys citellus (circles), T. pulchellus (triangles), and T. pusillus (squares) revised in this work (numbers corresponds to those of the Appendix 1) and additional localities for Thylamys pulchellus (from Braun et al., 2005): Argentina: Catamarca: 47.- Capayán, Chumbicha, $0.5 \mathrm{~km}$ E of Highway 38 along 60 (-28.852853 $\left.{ }^{\circ} \mathrm{S},-66.236150^{\circ} \mathrm{W}\right)$; San Juan: 48.- Caucete, Quebrada de Las Flores, $4 \mathrm{~km}$ E and $5 \mathrm{~km}$ N Guayamas (ca.

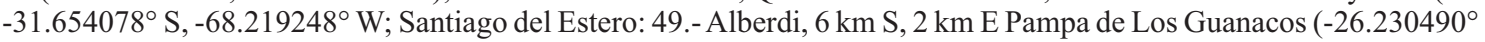
$\left.\mathrm{S},-61.826564^{\circ} \mathrm{W}\right)$; 50.- Choya, Salinas de Ambargasta app. $8 \mathrm{~km}$ SE Cerro Rico (-29.173021 $\left.{ }^{\circ} \mathrm{S},-64.403726^{\circ} \mathrm{W}\right)$; and T. pusillus: Paraguay: Boquerón: 51.- Trans-Chaco Highway, $460 \mathrm{~km}$ NW Villa Hayes (-22.366805 S, $-60.199926^{\circ} \mathrm{W}$; type locality, fixed by neotype selection [Voss et al., in press]).

FIGURA 1. Localidades de registro para los ejemplares de Thylamys citellus (círculos), T. pulchellus (triángulos) y $T$. pusillus (cuadrados) revisados en este trabajo (los números corresponden a los anotados en el Apéndice 1) y localidades adicionales para Thylamys pulchellus (tomadas de Braun et al., 2005): Argentina: Catamarca: 47.- Capayán, Chumbicha, $0.5 \mathrm{~km}$ E of Highway 38 along $60\left(-28.852853^{\circ} \mathrm{S},-66.236150^{\circ} \mathrm{W}\right)$; San Juan: 48.- Caucete, Quebrada de Las Flores, $4 \mathrm{~km}$ E and $5 \mathrm{~km} N$ Guayamas (ca. -31.654078 ${ }^{\circ}$ S, -68.219248 W; Santiago del Estero: 49.- Alberdi, $6 \mathrm{~km} \mathrm{S,} 2 \mathrm{~km} \mathrm{E}$ Pampa de Los Guanacos (-26.230490 S, -61.826564 W); 50.- Choya, Salinas de Ambargasta app. 8 km SE Cerro Rico (-29.173021 $\left.{ }^{\circ} \mathrm{S},-64.403726^{\circ} \mathrm{W}\right)$; y T. pusillus: Paraguay: Boquerón: 51.- Trans-Chaco Highway, $460 \mathrm{~km}$ NW Villa Hayes (-22.366805 $-60.199926^{\circ} \mathrm{W}$; localidad tipo, fijada por selección de neotipo [Voss et al., en prensa]).

of Thylamys pallidior (see Appendix 1) and used diagnostic traits annotated in the literature for $T$. macrurus (Voss et al. in press).

MoRPHOLOGIC DATA ANALYSIS. Nomenclature used to describe the skull and its structures follows Voss
\& Jansa (2009). Standard external measures for mammals were recorded from field catalogs or specimen tags: HB: head and body length; TL: tail length, HF: hind foot length (including the claw), and EL: ear length. Eight skull and dental measurements were recorded following Voss et al. (2004a); these 
TABLE I. Descriptive statistics for external and cranial variables of adult males and females (age classes 6 and 7) of Thylamys citellus, T. pulchellus, and T. pusillus. See materials and methods for the explanation of the abbreviatures; $\mathrm{Sd}$ $=$ standard deviation.

TABLA I. Estadísticos descriptivos para variables externas y craneanas de ejemplares adultos machos y hembras (clases de edad 6 y 7) de Thylamys citellus, T. pulchellus y T. pusillus. Véase materiales y métodos para una explicación de las abreviaturas; $\mathrm{Sd}=$ desviación estándar.

\begin{tabular}{llcccccccccccc}
\hline & & $\mathrm{HB}$ & $\mathrm{T}$ & $\mathrm{HF}$ & $\mathrm{EL}$ & $\mathrm{CBL}$ & $\mathrm{ZB}$ & $\mathrm{LIB}$ & $\mathrm{PL}$ & $\mathrm{PB}$ & $\mathrm{MTR}$ & LM & $\begin{array}{c}\text { MI- } \\
\text { M3 }\end{array}$ \\
\hline $\begin{array}{l}\text { Thylamys } \\
\text { citellus }\end{array}$ & Mean & 105.4 & 111.4 & 15.1 & 22.5 & 30.8 & 18.1 & 5.0 & 16.1 & 9.8 & 11.2 & 5.6 & 4.7 \\
& Minimum & 99.0 & 102.0 & 14.5 & 20.1 & 29.0 & 16.5 & 4.7 & 15.0 & 9.1 & 10.1 & 5.4 & 4.5 \\
& Maximum & 115.0 & 125.0 & 16.0 & 24.0 & 33.1 & 19.6 & 5.5 & 17.6 & 11.5 & 11.8 & 5.8 & 5.0 \\
& $\mathrm{Sd}$ & 7.8 & 8.9 & 0.5 & 1.6 & 1.7 & 1.3 & 0.3 & 1.0 & 1.0 & 0.6 & 0.2 & 0.2 \\
& $\mathrm{~N}$ & 5 & 5 & 5 & 5 & 5 & 5 & 5 & 5 & 5 & 5 & 5 & 5 \\
\hline $\begin{array}{l}\text { Thylamys } \\
\text { pulchellus }\end{array}$ & Mean & 82.7 & 96.6 & 12.4 & 17.8 & 24.7 & 14.1 & 4.1 & 13.0 & 8.1 & 9.6 & 4.7 & 4.2 \\
& Minimum & 62.0 & 79.0 & 10.0 & 13.0 & 23.9 & 13.4 & 3.6 & 12.5 & 7.5 & 8.2 & 4.3 & 3.9 \\
& Maximum & 96.0 & 108.0 & 17.0 & 23.0 & 26.4 & 15.0 & 4.7 & 13.7 & 8.5 & 10.4 & 5.0 & 4.6 \\
& Sd & 10.1 & 8.5 & 2.3 & 3.4 & 0.9 & 0.5 & 0.4 & 0.4 & 0.3 & 0.7 & 0.2 & 0.3 \\
& $\mathrm{~N}$ & 11 & 11 & 9 & 11 & 9 & 9 & 9 & 9 & 9 & 9 & 10 & 9 \\
\hline $\begin{array}{l}\text { Thylamys } \\
\text { pusillus }\end{array}$ & Mean & 100.0 & 113.6 & 14.2 & 20.5 & 26.3 & 15.1 & 4.1 & 14.0 & 8.6 & 10.2 & 5.2 & 4.6 \\
& Minimum & 70.0 & 85.0 & 11.0 & 13.0 & 24.4 & 12.7 & 3.7 & 10.0 & 7.0 & 9.5 & 4.1 & 3.8 \\
& Maximum & 120.0 & 134.0 & 22.0 & 25.0 & 29.6 & 16.7 & 4.8 & 16.0 & 9.4 & 11.1 & 6.5 & 9.1 \\
& Sd & 11.3 & 10.9 & 2.4 & 2.7 & 1.3 & 0.85 & 0.2 & 0.9 & 0.4 & 0.3 & 0.4 & 0.6 \\
& $\mathrm{~N}$ & 38 & 38 & 38 & 36 & 57 & 59 & 61 & 62 & 62 & 62 & 48 & 62 \\
\hline
\end{tabular}

are: condylobasal length (CBL), palatal length (PL), least interorbital breadth (LIB), palatal breadth (PB), zygomatic breadth (ZB), maxillary tooth row length (MTR), length of molars (LM), and length of M1-M3 (M1-M3). External and craniodental measurements are summarized in Table I. A principal component analysis was conducted using the software Statistica (StatSoft 2001), performed on the eight craniodental measurements previously defined, and considering only adult specimens (ages 6-7, sensu Tribe, 1990) without missing values. Principal components were extracted from a variance-covariance matrix and computed by using the craniodental variables after transformation to their natural logarithms. Nomenclature of colors follows Ridgway (1912).

Phylogenetic ANALYSES. Phylogenetic analyses were based on the first 801 base pairs of the mitochondrial gene that codes for cytochrome b. Sequences of 27 specimens belonging to six currently recognized species of Thylamys were analyzed (Table II). Our sampling lacks sequences representing T. macrurus, T. sponsorius, T. tatei, and T. velutinus. Haplotypes recovered from 10 specimens representing 10 other didelphid genera were used as outgroups. Thirtythree of the 37 sequences analyzed were retrieved from Genbank (Table I). We generated the sequences of the following three specimens from the Argentine Mesopotamia currently assigned to T. pusillus: CNP 1920, MACN 23459, and MACN 23460 as well as one of Cryptonanus chacoensis (GD 521) used as part of the outgroup. Laboratory procedures followed those of D'Elía \& Pardiñas (2004). New sequences were translated to amino-acids and no evidence of non-functionality was found. Sequences were aligned using Clustal X (Thompson et al. 1997) with default values for all alignment parameters; no adjustment by eye was needed. Observed percentage of sequence divergence was 
calculated with MEGA 4 (Tamura et al. 2007) ignoring those sites with missing data. Sequence alignment was subjected to maximum parsimony (MP; Farris, 1983) and Bayesian (Huelsenbeck et al. 2001) analyses. Characters used in MP analysis were treated as unordered and equally weighted. MP was conducted in PAUP* (Swofford 2000) with 200 replicates of heuristic search with random addition of sequences and TBR branch swapping. Nodal support was assessed with 1000 pseudoreplicates of Jackknife (JK; Farris et al. 1996), each with 33 $\%$ of data deletion and three replicates of random addition of sequences and TBR branch swapping. Bayesian analysis was conducted with MrBayes 3 (Ronquist \& Huelsenbeck 2003) by means of two independent runs with three heated and one cold Markov chains each. A model with six categories of base substitution, a gamma-distributed rate parameter, and a proportion of invariant sites was specified; all model parameters were estimated in MrBayes. Uniform interval priors were assumed for all parameters except base composition and GTR parameters, which assumed a Dirichlet process prior. Chains were allowed to run for three million generations; trees were sampled every 100 generations for each chain. To check that each run converged on a stable log-likelihood value, we plotted the log-likelihood values against generation time for each. The first $25 \%$ of the trees were discarded as burn-in and the remaining trees were used to compute a $50 \%$ majority rule consensus tree and obtain posterior probability (PP) estimates for each clade.

\section{RESULTS}

Morphometric ANALYSIS. The eigenvalues of the first three principal components were $4.80(60.01 \%)$, $1.13(14.22 \%)$, and $0.78(9.71 \%)$ respectively. Together, these three axes account for $83.94 \%$ of the total variance in our log-transformed craniodental measurement data. Loadings of the eight characters analyzed along each of the first three components are shown in Table III. Although there is an evident overlaping among the specimens included in the multivariate analysis, specimens referable to Thylamys pusillus (as that species is currently understood) split in three main groups geographically allopatric: one group is formed by Mesopotamian specimens, another by all Argentinean samples western of Paraná River (southern Chaco) with the exception of five specimens from Formosa Province, near the Argentinean-Paraguayan border, which groups with the Paraguayan samples to form the third group from the northern Chaco. In the bivariate plot of components I and II (Fig. 2) the overlaping is scarce, and the groups are mostly separated on the first component. Here the most dissimilar group is the one including specimens from Corrientes and Entre Ríos. On the other hand, the southern and northern Chacoan groups are poorly differentiated along the first and second components, as well as along the first and third components (Fig. 2). However, the southern group in always placed on the rigth part of the plot. Basically, the three groups discriminate by size in several cranial measurements as CBL, PL and ZB (Table III).

Phylogenetic inference. Maximum parsimony analysis recovered 45 shortest trees (length $=1416$ steps; $\mathrm{CI}=0.379$; $\mathrm{RI}=0.577$ ). The strict consensus of these trees (Fig. 3a) shows a well supported $(\mathrm{JK}=93)$ Thylamys clade, which has 19 nodes of which five involve polytomies. Specimens currently assigned to $T$. pusillus form a strongly supported $(\mathrm{JK}=100)$ clade sister to a clade $(\mathrm{JK}=89)$ form by the other two southern cone species included in the analysis, T. pallidior and T. elegans. Relationships of the other species are unresolved. Within the clade formed by specimens currently assigned to $T$. pusillus there are three main clades geographically allopatric and coincident with those found in the morphometric analysis. Specimens from Argentina west of Paraná River (i.e., from Catamarca, Santiago del Estero, and San Juan Provinces) form a strongly supported clade $(\mathrm{JK}=100)$. Specimens from Argentine Mesopotamia (i.e., east of Paraná River in Entre Ríos province) form another strongly supported clade $(\mathrm{JK}=98)$. Both the western Paraná and Mesopotamian clades are sister groups in a relatively well supported clade ( $\mathrm{JK}=81$ ), which is sister to the clade formed by the single Paraguayan specimen included in the analysis. Results of the Bayesian analysis (Fig. 3b) are congruent with those of the MP analysis; the main difference is that, as is usually the case, the Bayesian tree is more resolved (i.e., T. venustus appears as sister to $T$. cinderella; T. karimii is sister to the clade formed by the other Thylamys) than the MP tree. The Bayesian analysis is totally congruent with the MP tree in the topology obtained from the haplotypes of specimens currently 
TABLE II. List of specimens from which haplotypes included in the phylogenetic analyses were recovered. For each sequence its Genbank accession numbers and the indication of study in which it was gathered are provided. For data of the specimens of Thylamys sequenced in this study see the Appendix. The specimen of Cryptonanus chaoensis (GD 521; GD: catalog number of Guillermo D’Elía) was collected in Paraguay, Caazapá, Estancia Dos Marías, 11.6 km S de las casas, costa del Río Tebicuary $\left(-26.758507^{\circ} \mathrm{S},-56.537503^{\circ} \mathrm{W}\right)$.

TABLA II. Lista de especímenes, de los cuales se recobraron los haplotipos incluidos en los análisis filogenéticos. Para todas las secuencias se proveen el número de acceso a Genbank y se indica el estudio en que fue generada. En relación a los datos de los especímenes de Thylamys secuenciados en este estudio ver el Apéndice 1. El espécimen de Cryptonanus chaoensis (GD 521; GD: número de catálogo de Guillermo D’Elía) fue colectado en Paraguay, Caazapá, Estancia Dos Marías, $11.6 \mathrm{~km} \mathrm{~S}$ de las casas, costa del Río Tebicuary $\left(-26.758507^{\circ} \mathrm{S},-56.537503^{\circ} \mathrm{W}\right)$.

\begin{tabular}{|c|c|c|c|c|}
\hline & Taxon & Catalog number & Accession Number & Reference \\
\hline \multicolumn{5}{|c|}{ Ingroup } \\
\hline 1 & T. cinderella & Arg 2234 & AY803332 & Braun et al. (2005a) \\
\hline 2 & T. cinderella & OMNH 22965 & AY803325 & Braun et al. (2005a) \\
\hline 3 & T. cinderella & OMNH 29975 & AY803327 & Braun et al. (2005a) \\
\hline 4 & T. cinderella & OMNH 29977 & AY803329 & Braun et al. (2005a) \\
\hline 5 & T. citellus & MACN 23459 & GQ911594 & This study \\
\hline 6 & T. citellus & MACN 23460 & GQ911593 & This study \\
\hline 7 & T. citellus & CNP 1920 & GQ911595 & This study \\
\hline 8 & T. elegans & MUSM 10738 & AF434179 & Meynard et al. (2002) \\
\hline 9 & T. elegans & NK 27583 & AF431929 & Palma et al. (2002) \\
\hline 10 & T. elegans & NK 96571 & AF434176 & Meynard et al. (2002) \\
\hline 11 & T. karimii & - & EF051700 & $\begin{array}{l}\text { Carvalho et al. } \\
\text { (unpublished) }\end{array}$ \\
\hline 12 & T. karimii & MN 36405 & EF 114742 & $\begin{array}{l}\text { Carvalho et al. } \\
\text { (unpublished) }\end{array}$ \\
\hline 13 & T. pallidior & CML 3192 & AY803311 & Braun et al. (2005a) \\
\hline 14 & T. pallidior & EP 440 & AF431923 & Palma et al. (2002) \\
\hline 15 & T. pallidior & FMNH 162495 & AJ628368 & Steiner et al. (2005) \\
\hline 16 & T. pallidior & NK 23533 & AF431924 & Palma et al. (2002) \\
\hline 17 & T. pallidior & NK 96057 & AF431930 & Palma et al. (2002) \\
\hline 18 & T. pallidior & OMNH 29957 & AY803300 & Braun et al. (2005) \\
\hline 19 & T. pallidior & OMNH 29964 & AY803297 & Braun et al. (2005) \\
\hline 20 & T. pulchellus & Arg 5420 & AY803322 & Braun et al. (2005) \\
\hline 21 & T. pulchellus & CML 3198 & AY803323 & Braun et al. (2005) \\
\hline 22 & T. pulchellus & OMNH 23479 & AY803321 & Braun et al. (2005) \\
\hline 23 & T. pulchellus & OMNH 23483 & AY803319 & Braun et al. (2005) \\
\hline 24 & T. pulchellus & OMNH 29961 & AY803320 & Braun et al. (2005) \\
\hline
\end{tabular}


Gayana 73(2), 2009

Continuación TABLA II

\begin{tabular}{|c|c|c|c|c|}
\hline 25 & T. pusillus & TK 66469 & AY803324 & Braun et al. (2005) \\
\hline 26 & T. venustus & NK 12671 & AF431922 & Palma et al. (2002) \\
\hline 27 & T. venustus & OMNH 29952 & AY803334 & Braun et al. (2005) \\
\hline \multicolumn{5}{|c|}{ Outgroup } \\
\hline 28 & Chironectes minimus & ROM FN-31677 & AJ628363 & Steiner et al. (2005) \\
\hline 29 & $\begin{array}{c}\text { Cryptonanus chacoen- } \\
\text { sis }\end{array}$ & GD 521 & GQ911596 & This study \\
\hline 30 & $\begin{array}{l}\text { Gracilinanus micro- } \\
\text { tarsus }\end{array}$ & MVZ 182055 & AJ628369 & Steiner et al. (2005) \\
\hline 31 & $\begin{array}{c}\text { Lutreolina crassicau- } \\
\text { data }\end{array}$ & UMMZ 134018 & AJ628364 & Steiner et al. (2005) \\
\hline 32 & Marmosa lepida & AMNH 273186 & AJ606452 & Steiner et al. (2005) \\
\hline 33 & $\begin{array}{c}\text { Marmosa (Micoureus) } \\
\text { demerarae }\end{array}$ & MNFS 181 & U34673 & Patton et al. (1996) \\
\hline 34 & Marmosops impavidus & MVZ 171408 & U34669 & Patton et al. (1996) \\
\hline 35 & $\begin{array}{c}\text { Metachirus nudicau- } \\
\text { datus }\end{array}$ & MNFS 40 & U34672 & Patton et al. (1996) \\
\hline 36 & Monodelphis adusta & MVZ 171412 & U34677 & Patton et al. (1996) \\
\hline 37 & Philander opossum & MNFS 146 & U34679 & Patton et al. (1996) \\
\hline
\end{tabular}

assigned to T. pusillus, although is worth noting that the Mesopotamian clade is only moderately supported $(\mathrm{PP}=0.73)$.

TAXONOMY. Taken as a whole, our results allow us to distinguish three groups within the taxon currently recognized as Thylamys pusillus. This scenario is also supported by the fact that two of these groups do not fit with the emended diagnosis of T. pusillus provided by Voss et al. (in press). In addition, the specimens coming from the northern portion of the Argentine Humid Chaco, in Formosa Province (Fig. 1, Appendix 1) are morphologically closer to $T$. pusillus from Bolivia and Paraguay. The remaining specimens, which are split in two discrete groups, would correspond to two additional species. The genetic evidence and the morphological pattern (see below), indicate that the populations of the Argentine Mesopotamia (Entre Rios and Corrientes Provinces, Fig. 1), on the eastern side of Paraná River, can be assigned to T. citellus (Thomas, 1912), which is among the largest species of Thylamys and has its type locality in the province of Corrientes. The known distribution of T. citellus is restricted by the Paraná and Uruguay rivers. On the other hand, the small specimens coming from the western side of the Paraná River, in the more extensive Dry Chaco eco-region, are clearly distinguishable from Mesopotamian populations (T. citellus), and from those in northern Formosa and Paraguay ( $T$. pusillus). Genetic divergence and morphological characters support the idea that such specimens could be assigned to a species inhabiting most of the Dry Chaco eco-region in northern and central Argentina. These populations can be assigned to T. pulchellus Cabrera, 1934, based on a specimen from the dry Chacoan forest of Santiago del Estero Province (Fig. 1) whose morphology resembles that of examined vouchers specimens from southwestern Chaco, southeastern Salta, and Santiago del Estero (see Appendix 1). In summary, with the evidence at hand, we recognize three distinct species within the Thylamys pusillus complex: T. citellus, $T$. pulchellus, and T. pusillus (sensu stricto). Below, 
Taxonomy of Thylamys: TETA, P. ET AL.

TABLE III. Results of principal components analysis of eight craniodental measurements of adult specimens of Thylamys (age clases 6-7; $\mathrm{n}=71$ ). See Materials and Methods for abbreviations.

TABLA III. Resultados del análisis de componentes principales para ocho medidas craneodentarias de ejemplares adultos de Thylamys (clases de edad 6-7; $\mathrm{n}=71$ ). Véase Materiales y Métodos para una explicación de las abreviaturas.

\begin{tabular}{cccc}
\hline & PC I & PC II & PC III \\
\hline ZB & $-0,875088$ & 0,230073 & 0,102571 \\
LIB & $-0,714867$ & 0,029994 & 0,467879 \\
CBL & $-0,939601$ & 0,201280 & 0,020560 \\
PL & $-0,942238$ & 0,139973 & $-0,007780$ \\
PB & $-0,782272$ & 0,217435 & $-0,139311$ \\
MTR & $-0,858232$ & $-0,288868$ & $-0,058945$ \\
LM & $-0,290703$ & $-0,865606$ & 0,316361 \\
M1-3 & $-0,566221$ & $-0,378527$ & $-0,651012$ \\
\hline Eigenvalue & 4,801102 & 1,137217 & 0,776697 \\
\% Variance & 60,01378 & 14,21522 & 9,70872 \\
\hline
\end{tabular}
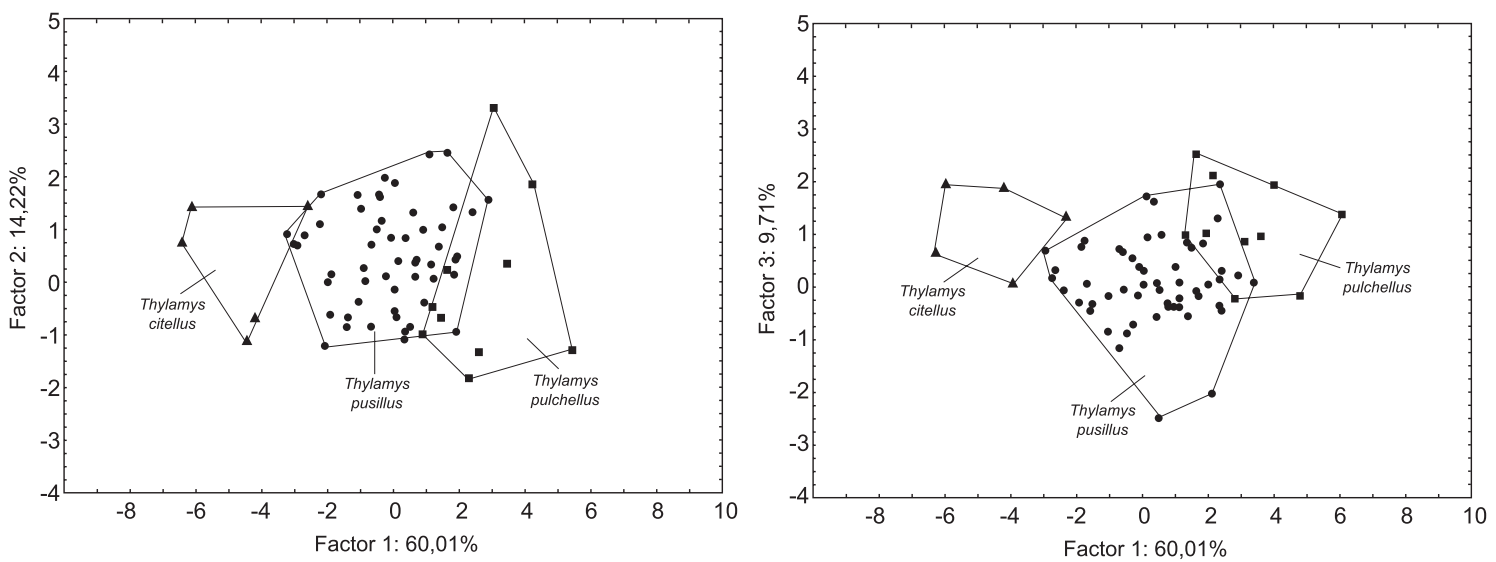

FIGURE 2. Specimen scores of adult individuals of Thylamys (age clases 6-7; $\mathrm{n}=71$ ) for principal components 1 and 2 and 1 and 3 extracted from the variance-covariance matrix of 8 craniodental distances (see text and Table II).

FiguRa 2. Proyección de los ejes 1 y 2 y 1 y 3 del análisis de componentes principales generado a partir de una matriz de varianza-covarianza de 8 medidas craneo dentarias para ejemplares adultos de Thylamys (clases de edad 6-7; $\mathrm{n}=71$ ).

we offer emended diagnoses and comparisons for $T$. citellus and T.pulchellus. For the emended diagnosis of T. pusillus see Voss et al. (in press).

\section{Thylamys citellus (Thomas, 1912)}

Figs. 1-7, Table II-IV

HoLOTYPE. B.M. 98. 8. 19. 9., collected $25^{\text {th }}$ July, 1895, by R. Perrens in Goya, Corrientes, Argentina.
Alt. 600' (Fig. 4).

Type LocaltTy. Goya, Corrientes Province, Argentina $\left(-29.145458^{\circ} \mathrm{S},-59.268165^{\circ} \mathrm{W}\right)$ (Fig. 1).

TAXONOMIC REMARKs. The first Thylamys specimen from Corrientes Province, Argentina was identified by Thomas (1894) as Micoureus griseus Desmarest, 1827. Two years later, Thomas (1896) used the name Marmosa marmota for the same specimen. 

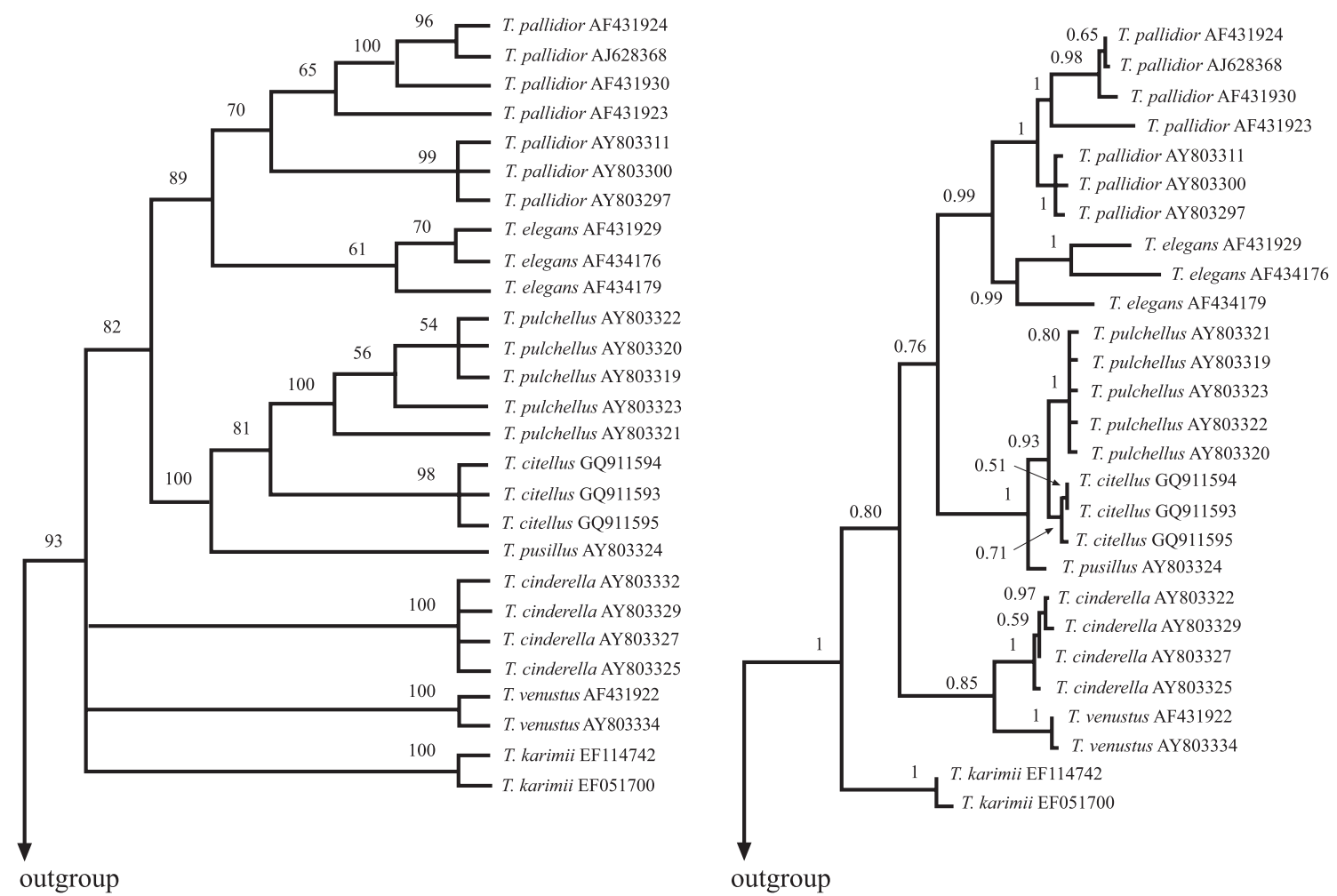

FIGURE 3. A) Strict consensus tree of the 55 most-parsimonious trees (length: 1416 steps; CI: 0.379; RI: 0.577) obtained in the maximum-parsimony analysis of cytochrome b gene sequences. Numbers indicate values of Jackknife support of the nodes at their right. Only Jackknife values above $50 \%$ are shown. Genbank accession numbers of analyzed sequences are included at terminal labels. B) Majority-rule consensus resulting from the Bayesian analysis of cytochrome b gene sequences. Numbers indicate posterior probability values of the nodes at their right. Genbank accession numbers of analyzed sequences are included at terminal labels.

FIgURA 3. A) Consenso estricto de 55 árboles más parsimoniosos (longitud: 1416 pasos; IC: 0.379; IR: 0.577) obtenidos en el análisis de máxima parsimonia de secuencias del gen del citocromo b. Los números corresponden a valores de apoyo de Jackknife de los nodos a su derecha. Sólo se muestran valores de Jackknife mayores a 50\%. Los números de acceso a Genbank de las secuencias analizadas se incluyen en la etiquetas de las terminales. B) Consenso por la regla de la mayoría, resultado del análisis Bayesiano de secuencias del gen del citocromo b. Los números corresponden a valores de probabilidad a posteriori de los nodos a su derecha. Los números de acceso a Genbank de las secuencias analizadas se incluyen en las etiquetas de las terminales.

Subsequently, after studying additional new specimens from Corrientes, Thomas (1912) described Marmosa citella, including in this species the specimen previously identified by him as Micoureus griseus and Marmosa marmota. The name Marmosa marmota (Oken, 1816), as used by Tate (1933) is not available (ICZN 1956), but the epithet marmota is alleged to have been made available inadvertantly by Thomas (1896: footnote; Creighton \& Gardner, 2008:114). Although Creighton \& Gardner (2008) argued that citella Thomas, 1912 is as a junior synonym of Marmosa marmota Thomas 1896, we prefer to use citellus because it is the more familiar name (marmota has not been used in the taxonomic literature for decades), and because it is not associated with any nomenclatural ambiguity (marmota was used by Tate for the species currently known as T. macrurus). The replacement of a traditionally used name by an obscure epithet formerly associated with a different species would needlessly confuse current usage, so we follow the recommendations of the ICZN [1999, Arts. 23.9.1.1 and 23.9.1.2] in maintaining citellus as the appropriate name for the Mesopotamian form of T. pusillus (sensu lato). 
Taxonomy of Thylamys: TETA, P. ET AL.

TABLE IV. Morphological comparison of Thylamys citellus, T. pulchellus, and T. pusillus.

TABLA IV. Comparación morfológica de Thylamys citellus, T. pulchellus y T. pusillus.

\begin{tabular}{|c|c|c|}
\hline Thylamys citellus & Thylamys pulchellus & Thylamys pusillus \\
\hline Tail bicolor, with white distal tip & Tail bicolor, including the tip & Tail bicolor, including the tip \\
\hline $\begin{array}{l}\text { Dorsal color pattern tricolor, with a } \\
\text { general cinnamon tint }\end{array}$ & $\begin{array}{l}\text { Dorsal color pattern tricolor, with a } \\
\text { general grayish brown tint }\end{array}$ & $\begin{array}{l}\text { Dorsal color pattern tricolor, with a } \\
\text { general dark-brown tint }\end{array}$ \\
\hline $\begin{array}{l}\text { Supraorbital beads usually well } \\
\text { developed }\end{array}$ & $\begin{array}{l}\text { Supraorbital beads slightly to well } \\
\text { developed }\end{array}$ & $\begin{array}{c}\text { Supraorbital beads slightly to well } \\
\text { developed }\end{array}$ \\
\hline $\begin{array}{l}\text { Postorbital constriction well } \\
\text { marked }\end{array}$ & $\begin{array}{l}\text { Postorbital constriction slightly to } \\
\text { well marked }\end{array}$ & $\begin{array}{l}\text { Postorbital constriction slightly to } \\
\text { well marked }\end{array}$ \\
\hline $\begin{array}{l}\text { Postorbital processes well defined } \\
\text { in adult individuals }\end{array}$ & $\begin{array}{l}\text { Postorbital processes usually } \\
\text { absent or slightly defined }\end{array}$ & $\begin{array}{l}\text { Postorbital processes usually absent } \\
\text { or slightly defined }\end{array}$ \\
\hline $\begin{array}{l}\text { Incisive foramina large, with } \\
\text { subparallel medial and lateral } \\
\text { margins }\end{array}$ & $\begin{array}{l}\text { Incisive foramina anteriorly } \\
\text { expanded and narrow in its } \\
\text { posterior portion }\end{array}$ & $\begin{array}{c}\text { Incisive foramina anteriorly } \\
\text { expanded and narrow in its posterior } \\
\text { portion }\end{array}$ \\
\hline $\mathrm{P} 2<<\mathrm{P} 3$ & $\mathrm{P} 2<\mathrm{P} 3$ & $\mathrm{P} 2<\mathrm{P} 3$ \\
\hline $\begin{array}{c}\text { Stylar cusp C in M3 usually well } \\
\text { marked }\end{array}$ & $\begin{array}{l}\text { Stylar cusp C in M3 slightly to } \\
\text { well marked }\end{array}$ & $\begin{array}{c}\text { Stylar cusp C in M3 usually absent or } \\
\text { indistinct }\end{array}$ \\
\hline
\end{tabular}

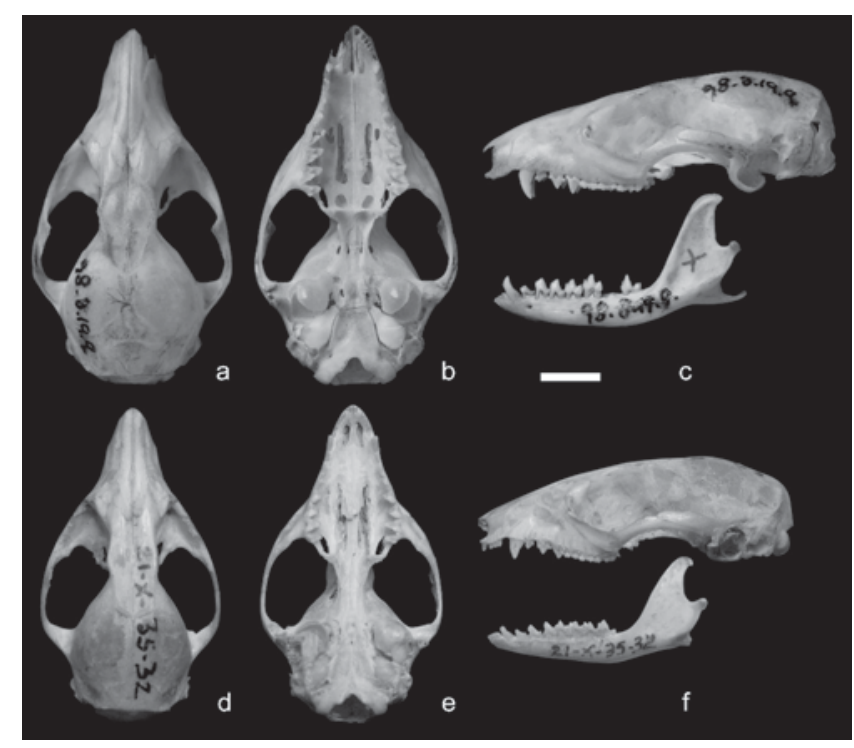

FIgURE 4. Dorsal, ventral, and lateral views of skull and labial view of the mandible of the holotypes of: a-c) Marmosa citella Thomas, 1912 (B.M. 98. 8. 19. 9), and d-f) Marmosa janetta pulchella Cabrera, 1934 (MLP 21.X.35.32). Scale bar $=5 \mathrm{~mm}$.

Figura 4. Vista dorsal, ventral y lateral del cráneo y vista labial de la mandíbula de los holotipos de: a-c) Marmosa citella Thomas, 1912 (a, b y c; B.M. 98. 8. 19. 9) y d-f) Marmosa janetta pulchella Cabrera, 1934 (MLP 21.X.35.32). Escala $=5 \mathrm{~mm}$. 
EMENDED DIAGNOSIS. A member of the didelphid genus Thylamys intermediate in size between $T$. pusillus and T. macrurus, characterized by a unique combination of morphological traits including a distinct tricolored pattern with a general cinnamon tint; tail longer than head and body, bicolored proximally (dark above, whitish below) but with the terminal $1 / 5$ to $1 / 4$ entirely white; skull robust with zygomatic arches proportionally wide relative to cranial length; supraorbital ridges well developed; postorbital constriction well marked; incisive foramina large, with subparallel medial and lateral margins; premaxillary-maxillary suture just above or posterior to the I5 alveolus; posterolateral palatal foramina long (extending to, or surpassing, the protocone of M4 on each side); and third upper molar with a marked stylar cusp C (Figs. 5-7).

Description. Thylamys citellus is a large, longtailed mouse opossum, with a brownish, soft, and fine dorsal pelage showing a conspicuous tricolor pattern with a general cinnamon tint (Fig. 5). Middorsal region from the ears to the hind-limbs is Raw Umber, while the sides are Wood Brown. The dorsal pelage is long and dense; guard hairs $(10-11 \mathrm{~mm})$ are brownish, darker at their bases; cover hairs are short (8-9 $\mathrm{mm})$ and four-banded, with a grayish base (2/3), followed by a narrow dark brown band, and creamy brown distal portions and dark tips. The venter, from the cheeks to the anus, is covered by entire creamy white hairs $(7-8 \mathrm{~mm})$. The gular region is white or has a yellowish tint in some individuals. The head is paler, with the snout characterized by a distinct dark line. The eye ring is moderately developed and dark brown, extending slightly to the nose. The rhinarium has two ventrolateral grooves flanking the median sulcus on each side. The vibrissae are mostly dark brown, except for the interramal hairs (which are whitish) and some large mystacial hairs that have whitish distal portions. The ears are

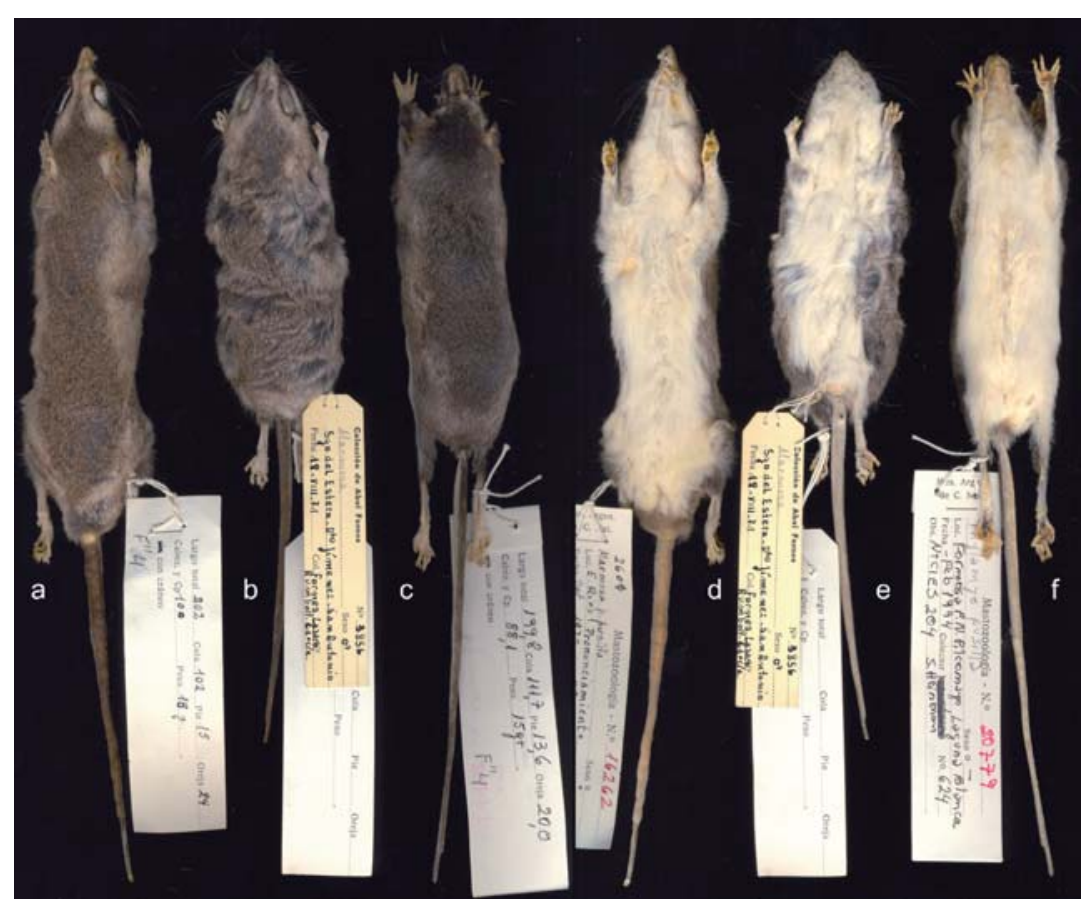

Figure 5. Dorsal and ventral views of study skins of a, d) Thylamys citellus (MACN 16262: Argentina, Entre Ríos, Pronunciamiento); b, e) T. pulchellus (MACN 17279: Argentina, Santiago del Estero, San Antonio); and c, f) T. pusillus (MACN 20779: Argentina, Formosa, Laguna Blanca).

Figura 5. Vistas dorsal y ventral de pieles de estudio de a, d) Thylamys citellus (MACN 16262: Argentina, Entre Ríos, Pronunciamiento); b, e) T. pulchellus (MACN 17279: Argentina, Santiago del Estero, San Antonio) y c, f) T. pusillus (MACN 20779: Argentina, Formosa, Laguna Blanca). 
large and rounded, partially covered by very short grayish-brown hairs, and apparently naked without magnification. The skin of the ears is dark brown at the tip and yellowish at the base. Behind each ear there is a conspicuous tuft of whitish hairs. The fore and hind limbs are whitish, without color differentiation between the dorsum and the palmar and plantar surfaces. The feet are large, and all the toes have large, white, ungual tufts. The toes are long, with short claws that do not surpass the apical pads on the forefeet, but are slightly longer on the hindfeet. Both manus and pes have six large, nearly ovoid, separate pads. Palmar and plantar surfaces are covered with large granules and dermatoglyphs. The tail is long, slightly incrassated in some individuals (6-7 $\mathrm{mm}$ in diameter), apparently naked without magnification, and bicolored. The base of the tail (ca. $9 \mathrm{~mm}$ ) is slightly covered by the body pelage. The tail dorsum is brownish, sharply demarcated from the whitish venter. The distal tip (1/5 to $1 / 6)$ of the tail is entirely white. Caudal scales are arranged in annular series. The ventral surface of the tail tip (15 $\mathrm{mm}$ ) is modified for prehension, with a naked median grove and a fleshy apical pad bearing dermatoglyphs. Females do not have a pouch, and 13 mammae are arranged in a nearly circular pattern in the abdomen (6-1-6). The skull is robust, with wide zygomatic arches relative to cranial length (the average ratio of zygomatic breadth to condylobasal length $\times 100$ is about 56-61\%; Fig. 6). The interorbital region is moderately narrowed, and mature adults often have pointed postorbital processes from which sharp ridges converge posteriorly onto the parietals. The postorbital constriction is well-marked. The braincase is inflated, sometimes with weakly defined temporal ridges. The lambdoidal crests are slightly or moderately developed. In lateral view, the premaxillary-maxillary suture is posterior to the I5 alveolus. Two lacrimal foramina are contained within the anterior orbital margin, being small and

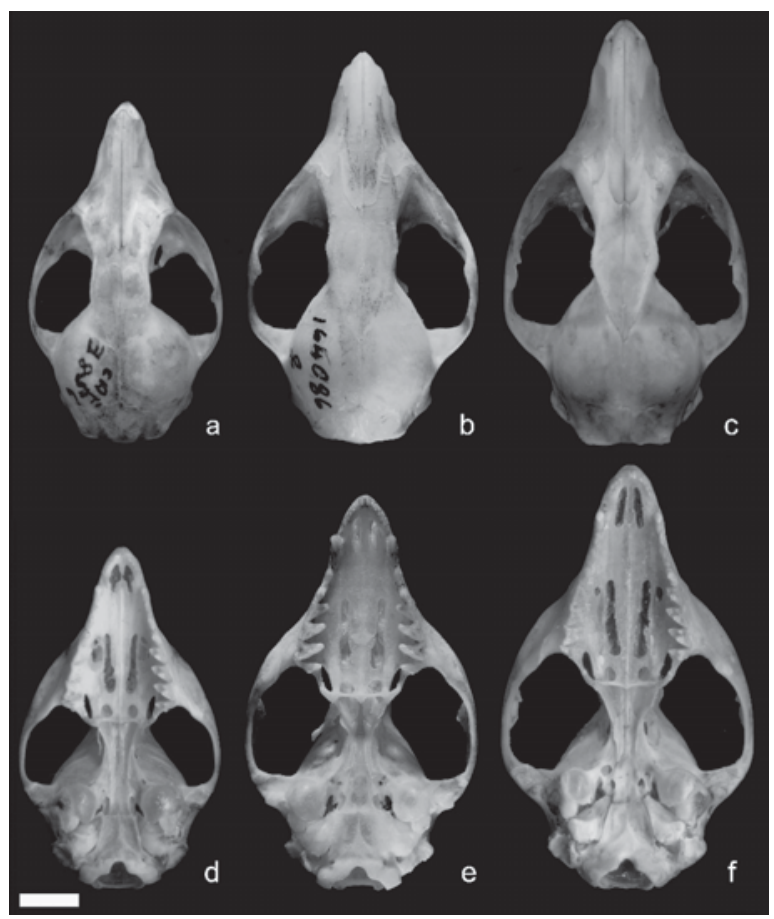

Figure 6. Dorsal and ventral views of the skulls of: a, d) Thylamys pulchellus (MACN 17279: Argentina, Santiago del Estero, San Antonio); b, e) T. pusillus (FMNH 164086: Paraguay, Boquerón, Schmidt Ranch, $10 \mathrm{~km}$ east Corrales); and c, f) T. citellus (MACN 23459: Argentina, Entre Ríos, Parque Nacional El Palmar). Scale bar $=5 \mathrm{~mm}$.

Figura 6. Vista dorsal y ventral de los cráneos de: a, d) Thylamys pulchellus (MACN 17279: Argentina, Santiago del Estero, San Antonio); b, e) T. pusillus (FMNH 164086: Paraguay, Boquerón, Schmidt Ranch, 10 km east Corrales) y c, f) T. citellus (MACN 23459: Argentina, Entre Ríos, Parque Nacional El Palmar). Escala $=5 \mathrm{~mm}$. 

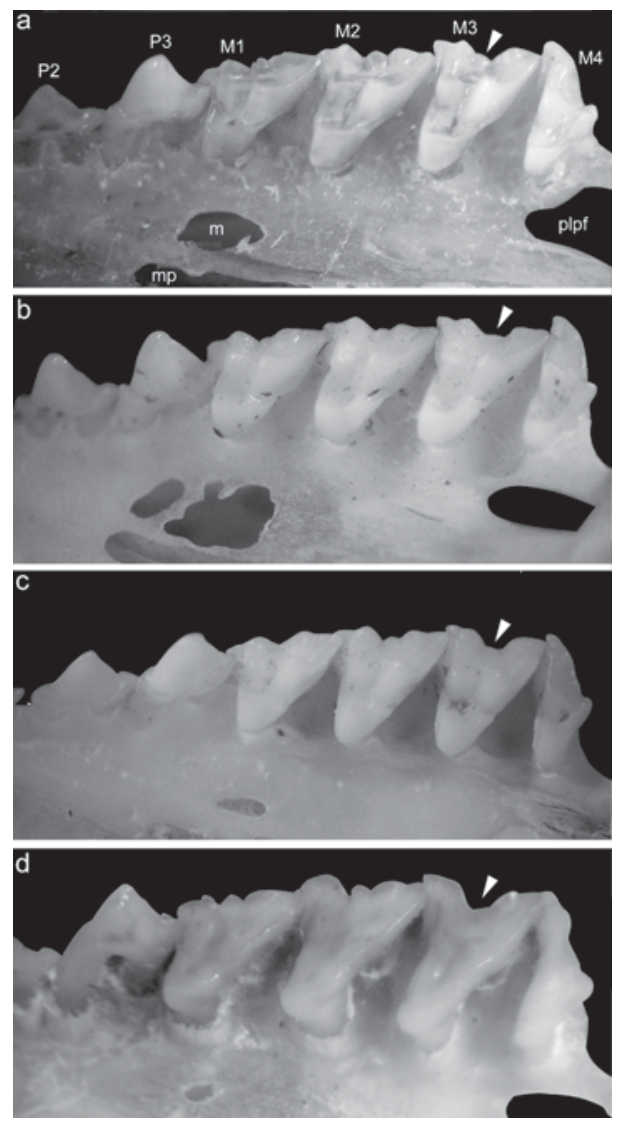

FIGURE 7. Occlusal surface of the right upper molar series of: a) Thylamys citellus (MACN 23459: Argentina, Entre Ríos, Parque Nacional El Palmar); b) T. pulchellus (MACN 17279: Argentina, Santiago del Estero, San Antonio); c) T. pusillus (MACN 20779: Argentina, Formosa, Laguna Blanca); and d) T. pusillus (FMNH 164086: Paraguay, Boquerón, Schmidt Ranch, $10 \mathrm{~km}$ east Corrales) showing the level of development of stylar cusp C (indicated by the arrow). Abbreviatures: P2, P3: upper second and third premolar; M1, M2, M3, M4; upper first, second, third and fourth molar; m: maxillary fenestra; $\mathrm{mp}$ : maxillopalatine fenestra; plpf: posterolateral palatal foramen.

Figura 7. Superficie oclusal de la serie molar superior izquierda de: a) Thylamys citellus (MACN 23459: Argentina, Entre Ríos, Parque Nacional El Palmar); b) T. pulchellus (MACN 17279: Argentina, Santiago del Estero, San Antonio); c) T. pusillus (MACN 20779: Argentina, Formosa, Laguna Blanca) y d) T. pusillus (FMNH 164086: Paraguay, Boquerón, Schmidt Ranch, $10 \mathrm{~km}$ east Corrales) mostrando el nivel de desarrollo de la cúspide estilar $\mathrm{C}$ (indicada con la flecha). Abreviaturas: P2, P3: segundo y tercer premolar superior; M1, M2, M3, M4; primero, segundo, tercero y cuarto molar superior; $\mathrm{m}$ : fenestra maxilar; mp: fenestra maxilopalatina; plpf: foramen palatal posterolateral. slightly visible in lateral view. The nasals are long, with subparallel lateral margins, and have a slight expansion at the maxillo-frontal suture, narrowing slightly behind it. The infraorbital foramen is large and is located just above P3. The zygomatic arches are conspicuously expanded and the external surface of the jugals exhibit a conspicuous concavity along their anterior portion. The incisive foramina are large, with subparallel medial and lateral margins, reaching in its posterior extension the midline between canines. The palate is highly fenestrated, showing maxillopalatine, palatine, and maxillary openings. The maxillopalatine fenestrae are large and wide, extending on each side from the anterior portion of P3 to the anterior portion of M4. The maxillary fenestrae are small (sometimes unilaterally present) and are located between M1 and the maxillopalatine fenestrae. The posterolateral palatal foramina are large and wide, reaching or surpassing the lingual apices of the protocones of M4. The alisphenoid tympanic wings are small and almost spherical. The I 2 to I5 are subequal in size, nearly rhomboidal, and increasing in breadth from front to back. Canines are large and lack accessory cusps. P3 is larger than P2; $\mathrm{P} 1$ is present and smaller than other premolars but not vestigial. The upper molars are dilambodont, compressed antero-posteriorly (especially M4), and highly carnassialized, increasing in width from M1 to M4. The ectoflexus is absent on M1, very shallow on M2, and distinct on M3. Stylar cusp C is well developed on the upper molars, being similar in size to stylar cusps B and D in M1, and smaller than stylar cusps B and D in M2 and M3 (Fig. 7). The horizontal and ascending rami of the mandible form an open angle. The lower incisors have distinct lingual cusps. A small, sometimes indistinct posterior cusp is present on $\mathrm{c} 1$. The second and third lower premolars (p2 and p3) are subequal in size. The trygonid increases in length from $\mathrm{m} 1$ to $\mathrm{m} 3$; the talonid is nearly squared. The hypoconid on $\mathrm{m} 3$ is not labially salient; the entoconid is large and well developed on m1-m3. Observed genetic distance among studied haplotypes of the cytochrome $b$ gene (first $801 \mathrm{bp}$ ) recovered from three specimens of $T$. citellus is $0.34 \%$.

COMPARISONS. The known geographic range of $T$. citellus is adjacent to the distributions of three congeneric species, T. macrurus, T. pusillus, and T. pulchellus (Fig. 1). Thylamys macrurus is larger than T. citellus, especially in molar dimensions (length 
of upper molar row $=5.3-5.6 \mathrm{~mm}$ vs. 4.5-5.0 mm; Table II) and has much smaller posterolateral palatal foramina (see Carmignotto \& Monfort 2006: Fig. 6). Thylamys pusillus is slightly smaller (intermediate in size between $T$. citellus and $T$. pulchellus), lacks a pale tail-tip, has a darker dorsal coloration, and usually lacks well developed supraorbital ridges and stylar cusp C on M3 (Fig. 5-7, Table IV). Thylamys pulchellus is much smaller than T. citellus (length of upper molar row usually $<4.5 \mathrm{~mm}$; Table II), has grayish-brown dorsal pelage, and lacks a pale tail-tip. Additionally, the premaxillary-maxillary suture in both T. pulchellus and T.pusillus is anterior to the I5 alveolus, while in T. citellus this suture is posterior to I5 (Fig. 5-7, Table IV). Observed genetic distance in the first 801 $\mathrm{bp}$ of the cytochrome $\mathrm{b}$ gene between $T$. citellus and T. pulchellus is $4.73 \%$ and between T. citellus and T. pusillus is $5.06 \%$ (Fig. 3).

Measurements. External and craniodental measurements of T. citellus are provided in Table II.

Habitat And Distribution. T. citellus is found in the Southern Cone Mesopotamian Savanna and the Mesopotamian sector of the Humid Pampas eco-regions (sensu Olson y Dinerstein 2002) in the Argentine provinces of Entre Ríos and Corrientes provinces (Fig. 1). The landscape in this area is a mixture of grassy savannas, open grasslands and vast wetlands with patches of subtropical gallery forest, xerophytic woodlands, and palm savannas. The region is highly threatened due to destruction and degradation of the natural habitat by housing, cattle ranching and agriculture (Olson et al. 2001). The known distributional range of $T$. citellus is limited by the Paraná River to the north and west, and by the Uruguay River and the flooded grasslands of the Iberá wetlands to the east. No other Thylamys species is sympatric with T. citellus. Gonzalez et al. (2000) reported a specimen of Thylamys from Uruguay (east of the Uruguay River), but they did not identify it to the species level. We did not directly study this Uruguayan specimen, but an inspection of the figure provided by Gonzalez et al. (2000) suggests it may not belong in Thylamys because its nasals are not parallel-sided and have a conspicuous expansion at their posterior portion (Gonzalez et al. 2000: Fig. 1). A direct inspection of the specimen would clarify this issue.
Thylamys pulchellus (Cabrera, 1934)

Figs. 1-7, Table II;IV

Holotype. MLP 21.X.35.32 (adult female); collected by Jorge Argañaraz and donated to MLP by Ángel Cabrera (Cabrera 1934) (Fig. 4).

Type Locality. "Los Robles, Santiago del Estero" (Cabrera, 1934) (Fig. 1).

TAXONOMIC REMARKS. The type material of pulchellus is from Santiago del Estero Province in the western Argentinean portion of the Dry Chaco eco-region. Voss et al. (in press; see also Voss \& Jansa 2009) suggested that an older available name for this species could be bruchi Thomas, 1921, with type locality in Alto Pencoso, north of San Luis Province. Although bruchi was included in the synonymy of Thylamys pallidior by Gardner (2005) and Creighton \& Gardner (2008), a cursory examination of the type specimen of bruchi, housed at the British Museum, reveals the presence of distinct maxillary vacuities and well developed stylar cusp C on M1 and M2 that better match with the diagnostic traits of $T$. pulchellus (as recognized herein) than with those of $T$. pallidior. However, bruchi lacks well defined supraorbital borders, and has large auditory bullae, resembling those of $T$. pallidior, so we provisionally follow the opinion of Tate (1933), who allied bruchi with pallidior on the basis of its coloration, body proportions, and some cranial features (e.g., development of the auditory bullae). Part of this confusing situation is due to the fact that the type specimen of bruchi is a young individual without the complete dentition erupted. It is also relevant that other examined specimens from San Luis Province, including some from near the type locality of bruchi, clearly fit the diagnosis of T. pallidior. Additional genetic and morphological evidence from topotypic material of bruchi, as well a thorough examination of the type specimen is highly necessary to assess the status of this nominal taxon.

Emended Diagnosis. A small member of the didelphid genus Thylamys, characterized by a unique combination of morphological traits including a moderately marked tricolored pattern with a general grayish-brown appearance; tail longer than head and body and sharply bicolored (dark above, whitish below); skull small but strongly built; supraorbital ridges slightly to well developed; postorbital 
constriction well marked; incisive foramina anteriorly expanded and narrow in their posterior portion; premaxillary-maxillary suture anterior or just above I5 alveolus; long posterolateral palatal foramina (extending to, or surpassing, the protocone of M4 on each side); and third upper molar with a marked stylar cusp C.

DESCRIPTION. Thylamys pulchellus is a small, longtailed mouse-opossum, with soft, fine, grayishbrown dorsal pelage showing a moderately marked tricolor pattern (Fig. 5). The mid-dorsal fur from the ears to the hind-limbs is Warm Sepia to Sepia, while the flanks are Hair Brown. Cover hairs (7-8 $\mathrm{mm}$ ) are four banded, with gray bases (4/5), middle portions dark brown to creamy brown, and dark tips. Ventral hairs, from the cheeks to the anus, are entirely creamy white $(5-6 \mathrm{~mm})$. The head is paler, with the snout characterized by a distinct dark line. The eye ring is moderately developed and dark brown, extending slightly to the nose. The rhinarium has two ventrolateral grooves flanking the median sulcus on each side. The vibrissae are mostly dark brown, except for the interramal hairs (which are whitish), and some large mystacial hairs that have whitish distal portions. The ears are large and rounded, entirely covered by very short grayish-brown hairs and apparently naked without magnification. The fore and hind limbs are whitish, without color differentiation between the dorsum and the palmar and plantar surfaces. The feet are small, and all the toes have large, white, ungual tufts. The toes are long, with short claws that do not surpass the apical pads in forefeet, but are slightly longer in the hindfeet. Both manus and pes have six large, ovoid, separate pads. The tail is long, slightly incrassated $(6-7 \mathrm{~mm}$ in diameter) in some individuals, apparently naked without magnification, and almost bicolored. The tail dorsum is brownish, sharply demarcated from the whitish venter. Caudal scales are arranged in annular series. The ventral surface of the tail tip (11-12 $\mathrm{mm})$ is modified for prehension, with a naked median grove and a fleshy apical pad bearing dermatoglyphs. Females do not have a pouch. The skull is small but strongly built, with wide zygomatic arches relative to cranial length (the average ratio of zygomatic breadth to condylobasal length $\times 100$ is about 55-60\%) (Fig. 6). The interorbital region is narrow, and the supraorbital margins are slightly to distinctly beaded. The postorbital constriction is indistinct in some individuals but well marked in others. The braincase is inflated, sometimes with weakly defined temporal ridges. The lambdoidal crests are inconspicuous. In lateral view, the premaxillary-maxillary suture is anterior to the I5 alveolus. The lacrimal foramina are contained within the anterior orbital margin, being usually large and well visible in lateral view. The nasals are long, with subparallel lateral margins, and have a slight expansion at the maxillo-frontal suture, narrowing slightly behind it. The infraorbital foramen is large and is located just above P3. The external surface of the jugals exhibits a conspicuous concavity along their anterior portion. The incisive foramina are large, anteriorly expanded and narrow in their posterior portion, reaching the anterior line between canines. The palate is highly fenestrated, showing maxillopalatine, palatine, and maxillary openings. The maxillopalatine fenestrae are large and wide, extending on each side from the commisure between P2 and P3 to the middle portion of M3. The maxillary fenestrae are large, extending from the P3 to the M1-M2 commissure. The posterolateral palatal foramina are large and wide, surpassing the lingual apices of the protocone of M4 on each side. The alisphenoid tympanic wings are small and almost spherical. The upper incisors (I2-I5) are subequal in size, nearly rhomboidal, and increasing in breadth from front to back. The canines are large and lack accessory cusps. The third upper premolar (P3) is slightly larger than P2; $\mathrm{P} 1$ is present and smaller than other premolars but not vestigial. The upper molars are dilambodont, compressed antero-posteriorly (especially the M4), and highly carnassialized, increasing in width from M1 to M4. The ectoflexus is absent on M1, very shallow on M2, and distinct on M3. Stylar cusp C is well developed on M1-M3, although it is smaller than stylar cusps B and D (Fig. 7). The horizontal and ascending rami of the mandible form an open angle. The lower incisors have indistinct lingual cusps. The lower canine has a small, usually well marked, posterior cusp. The second and third lower premolars are subequal in size. The trigonid increases in length from $\mathrm{m} 1$ to $\mathrm{m} 3$; the talonid is nearly squared. The hypoconid on $\mathrm{m} 3$ is not labially salient; the entoconid is large and well developed on m1-m3. Observed genetic distance among studied haplotypes corresponding to the first $801 \mathrm{bp}$ of the cytochrome $\mathrm{b}$ gene recovered from specimens of T. pulchellus is $1.29 \%$. The karyotype 
is $2 \mathrm{n}=14, \mathrm{FN}=20$; the $\mathrm{X}$ chromosome is a small submetacentric and the $\mathrm{Y}$ chromosome is missing in somatic cells (Braun et al., 2005b).

Comparisons. The known geographic range of Thylamys pulchellus is adjacent to the distributions of three congeneric species, T. citellus, T. pallidior, and T. pusillus (Fig. 1). T. citellus is clearly larger than T. pulchellus, has a more cinnamon general appearance, has a white tail-tip (Fig. 5-7, Table IV). Thylamys pusillus is slightly larger than $T$. pulchellus, has darker fur, frequently lacks stylar cusp C on M3 (Fig. 7), and usually has much smaller maxillary vacuities. Observed genetic distance in the first $801 \mathrm{bp}$ of the cytochrome b gene between T. pulchellus and T. pusillus is $6.22 \%$ (Fig. 3). Thylamys pallidior has much longer fur (usually $>10 \mathrm{~mm}$ ) than T. pulchellus, has longer manual claws (always extending beyond the fleshy apical pad of each digit), larger bullae, consistently lacks maxillary fenestrae, and lacks and stylar cusp $\mathrm{C}$ on M1-M3.

Measurements. External and craniodental measurements of $T$. pulchellus are provided in Table II.

Habitat AND Distribution. T. pulchellus is endemic to the Dry Chaco eco-region (sensu Olson y Dinerstein 2002) of the provinces of Catamarca, Chaco, San Juan, Salta, and Santiago del Estero (Fig. 1), and perhaps also occurs in Formosa and Tucumán (see Flores et al. 2007). The landscape in this biome is a mixture of grasslands and xerophytic woodlands, now typically dominated by secondary growth forests of Schinopsis lorentzii, Aspidosperma quebracho-blanco, and Prosopis sp. Morphometric and morphological evidence suggests that both pulchellus and pusillus are present in Argentina. However, their distributional boundaries are unclear (see above). It is not currently known whether or not these species occur in sympatry along the transitional zone between the Dry and Humid Chaco (the latter inhabited by $T$. pusillus). At the same time, the geographic distribution of T. pulchellus to the west and south (Córdoba and Catamarca Provinces) remains unclear. In those areas it could overlap with $T$. pallidior (Thomas, 1902), from which it is clearly differentiable both morphologically and genetically (Fig. 3).

\section{DISCUSSION}

The number of recognized species within Thylamys has varied significantly during the last two decades. For instance, Gardner (1993) recognized only five species, while in the last treatise of South American marsupials Creighton \& Gardner (2008) recognize 10 (but see Voss \& Jansa, 2009). As currently recognized, T. pusillus is a complex of at least three diagnosable taxa, two of which (previously treated as synonyms of pusillus) are elevated to species level in this report. This taxonomic resolution, at least in part, was previously suggested by Voss et al. (in press), who reported some metric and dental differences between typical Paraguayan samples of T. pusillus (sensu stricto) and the Argentinean populations herein referred to $T$. pulchellus. In a broader context, our findings are in line with other recent and partially unexpected discoveries within the Didelphidae, such as the recent description of several cryptic species, and even genera (Flores et al. 2008, Voss \& Jansa, 2003; Voss et al. 2004a, 2004b, 2005).

Given our taxonomic results, the genus Thylamys is now composed of 11 species, of which 6 occur in Argentina and 2 are Argentinean endemics. Future studies should refine species boundaries within Thylamys. For instance, it seems worth investigating the degree of geographic differentiation within T.pallidior, another widely distributed species with populations ranging from northern Chile to Argentinean Patagonia (Creighton \& Gardner 2008), and a species that also shows phylogeographic structure (Fig. 3; Appendix 1; see also Braun et al. 2005a).

Thylamys citellus, T. pusillus, and T. pulchellus form a strongly supported clade (Fig. 3), which suggests that part of the diversification of Thylamys has occurred inside the La Plata River basin. Plausibly, certain natural geographical barriers such as major rivers might have played a strong role delimiting local species of Thylamys: the sister species T. citellus and T. pulchellus, are geographically separated by the large Paraná River, for example, whereas T. pulchellus and T. pusillus seems to be separated by the Bermejo River. Similarly, T. pusillus does not cross the Paraguay River and is thus restricted to the Dry Chaco. Additional studies, in line to those of Patton et al. (1994, 2000), together with further field collections, are needed to clarify if these rivers prompted the diversification of Thylamys or just operate as dispersal barriers. 


\section{ACKNOWLEDGMENTS}

Robert Baker (TTU), Bruce Patterson (FMNH), Kurt Schwerk (UCON), Rubén Barquez (CML), Ulyses Pardiñas (CNP), and Diego Verzi (MLP) kindly permitted us the study of Thylamys specimens under their care. Robert Voss and Sergio Solari made valuable comments that greatly improved the quality of this manuscript. We are also grateful to Isabel Gómez Villafañe and Ulyses Pardiñas, who generously shared some specimens collected by their research teams in Entre Ríos province. Special thanks to Louise Thomsett and Katie Anderson who kindly provided the photographs of Marmosa citella holotype. This research was partially funded by Fondecyt 11070157 (to G. D’Elía).

\section{REFERENCES}

AzAra, F. 1801. Essais sur l'histoire naturelle des quadrupédes de la province du Paraguay. Traduits sur le manuscrit inédit de l'auteur, Pra. M. L. E. Moreau-Saint-Méry. Paris: Charles Pougens, 2:1-499.

AzARA, F. 1802. Apuntamientos para la historia natural de los quadrúpedos del Paraguay y Río de la Plata. Madrid: La Imprenta de la Viuda de Ibarra, 2:2 (unnumbered), $\mathrm{x}+1-328$.

Braun, J.K., Van den Bussche, R.A., Morton, P.K. \& Mares, M.A. 2005a. Phylogenetic and biogeographic relationships of mouse opossums Thylamys (Didelphimorphia, Didelphidae) in southern South America. Journal of Mammalogy 86(1):147-159

Braun, J. K., Mares, M.A. \& Stafira, J.S. 2005b. The chromosomes of some didelphid marsupials from Argentina. In: Contribuciones mastozoológicas en homenaje a Bernardo Villa (Eds. SánchezCordero, V. \& Medellín, R.A.), pp. 59-66. Instituto de Biología, Universidad Nacional Autónoma de México, Instituto de Ecología, UNAM; CONABIO, México.

Cabrera, A. 1958. Catálogo de los mamíferos de América del Sur. Revista del Museo Argentino de Ciencias Naturales "Bernardino Rivadavia," Ciencias Zoológicas, $4: \mathrm{xvi}+\mathrm{iv}+308,1957$. [Dated 1957; published 27 March 1958, see notice on p. 308.].

CABrera, A. 1934. Dos nuevos micromamíferos del norte Argentino. Notas Preliminares del Museo del La Plata 3:123-128.

CARmignotto, A.P. \& Monfort, T. 2006. Taxonomy and distribution of the Brazilian species of Thylamys (Didelphimorphia: Didelphidae). Mammalia 2006(1-2):126-144.

Creighton, G.K. \& Gardner, A.L. 2008. Genus Thylamys
Gray, 1843. In: Mammals of South America, Volume I. Marsupials, Xenarthrans, Shrews, and Bats (Ed. Gardner, A.L.In Gardner, A.L.), pp. 107-117. University of Chicago Press, Chicago and London.

D’Elía, G. \& Pardiñas, U.F.J. 2004. Systematics of Argentinean, Paraguayan, and Uruguayan swamp rats of the genus Scapteromys (Rodentia, Cricetidae, Sigmodontinae). Journal of Mammalogy 85(5):897-910.

FARRIS, J.S. 1983. The logical basis of phylogenetic analysis. In: Advances in Cladistics: Proceedings of the Second Meeting of the Willi Hennig Society (Eds. Planick, N. \& Funk, V.), pp. 7-36. Columbia University Press, New York.

Farris, J.S., Albert, V.A., Källersjö, M., Lipscomb, D. \& Kluge, A.G. 1996. Parsimony jackknifing outperforms neighbor-joining. Cladistics 12(1):99-124.

FLORES, D.A. 2009. Phylogenetic analyses of postcranial skeletal morphology in didelphid marsupials. Bulletin of the American Museum of Natural History 320:1-81.

Flores, D.A., Díaz, M.M. \& BARquez, R.M. 2000. Mouse opossums (Didelphimorphia, Didelphidae) of northwestern Argentina: systematics and distribution. Zeitschrift fur Saugetierkunde 65(6):321-339.

Flores, D.A., Díaz, M.M. \& Barquez. 2007. Systematics and distribution of marsupials in Argentina: a review. University of California Publications in Zoology 134:579-669.

Flores, D.A., Barquez, R.M. \& Díaz, M.M. 2008. A new species of Philander Brisson, 1762 (Didelphimorphia, Didelphidae). Mammalian Biology 73(1):14-24.

Gannon, W.L., Sikes, R.S., \& The Animal Care and Use Committee of The American Society of Mammalogists. 2007. Guidelines of the American Society of Mammalogists for the use of wild mammals in research. Journal of Mammalogy 88(3):809-823.

GARDNER, A.L. 1993. Order Didelphimorphia. In: Mammal species of the world: a taxonomic and geographic reference (Eds. Wilson, D.E. \& Reeder, D.M.), 2nd ed., pp. 15-27. Smithsonian Institute Press, Washington.

GARDNER, A.L. 2005. Order Didelphimorphia. In: Mammal species of the world: a taxonomic and geographic reference (Eds. Wilson, D.E. \& Reeder, D.M.), 3rd ed., pp. 3-18. Johns Hopkins University Press, Baltimore.

Gardner A.L. \& Creighton, G.K. 1989. A new generic name for Tate's (1933) microtarsus group of South American mouse opossums (Marsupialia: Didelphidae). Proceedings of the Biological Society of Washington 102(1):3-7.

GonzÁlez, E.M., Saralegui, A.M. \& Fregueiro, G. 2000. The genus Thylamys Gray, 1843 in Uruguay (Didelphimorphia, Didelphidae). Boletín de la Sociedad Zoológica de Uruguay, 2da Época 
$12: 44-45$.

Huelsenbeck, J. P., Ronquist, F., Nielsen, R. \& Bollback, J.P. 2001. Bayesian inference of phylogeny and its impact on evolutionary biology. Science 294(5550):2310-2314.

ICZN. 1999. International code of zoological nomenclature. 4th ed. London: International Trust for Zoological Nomenclature.

JAnSA, S.A. \& Voss, R.S. 2000. Phylogenetic studies on didelphid marsupials I. Introduction and preliminary results from nuclear IRBP gene sequences. Journal of Mammalian Evolution 7(1):43-77.

Kirsch, J.A.W. \& Palma, R.E. 1995. DNA/DNA hybridization studies of carnivorous marsupials. V. A further estimate of relationships among opossums (Marsupialia: Didelphidae). Mammalia 59(3):403-425.

Meynard, A.P., Palma, R.E. \& Rivera-Milla, E. 2002. Filogeografía de las llacas chilenas del género Thylamys (Marsupialia, Didelphidae) en base a secuencias del gen mitocondrial citocromo b. Revista Chilena de Historia Natural 79(2):299306.

Olson, D.M., Dinerstein, E., Wikramanayake, E.D., Burgess,N.D., Powell, G.V.N., Underwood, E.C., D’Amico, J.A., Strand, H.E., Morrison, J.C., Loucks, C.J., AllnutT, T.F., Lamoreux, J.F., Ricketts, T.H., Itoua, I., Wettengel, W.W, KuRA, Y. \& KASSEM, H. 2001. Terrestrial ecoregions of the world: a new map of life on Earth. BioScience 51(11):933-938.

Olson, D.M. \& Dinerstien, E. 2002. The Global 200: Priority ecoregions for global conservation. Annals of the Missouri Botanical Garden 89(2):199-224.

Palma, R.E. \& Yates, T.L. 1998. Phylogeny of southern South American mouse opossums (Thylamys, Didelphidae) based on allozyme and chromosomal data. Zeitschrift für Saugetierkunde 63(1):1-15.

Palma, R.E., Rivera-Milla, E., Yates, T.L., Marquet, P.A. \& Meynard, A.P. 2002. Phylogenetic and biogeographic relationships of the mouse opossum Thylamys (Didelphimorphia, Didelphidae) in southern South America. Molecular Phylogenetics and Evolution 25(2):245-253.

Patton, J.L., Da Silva, M.N.F. \& Malcolm, J.R.1994. Gene genealogy and differentiation among arboreal spiny rats (Rodentia, Echimyidae) of the Amazon basin - a test of the riverine barrier hypothesis. Evolution 48(4):1314-1323.

Patton, J.L., Dos Reis, S.F. \& Da Silva, M.N.F. 1996. Relationships among didelphid marsupials based on sequence variation in the mitochondrial cytochrome $\mathrm{b}$ gene. Journal of Mammalian Evolution 3(1):3-29.

Patton, J.L., Da Silva, M.N.F. \& Malcolm, J.R. 2000. Mammals of the Rio Juruá and the evolutionary and ecological diversification of Amazonia. Bulletin of the American Museum of Natural History 244:1-306.
Reig, O. A., Kirsch, J.A.W. \& Marshall, L.G.1987. Systematic relationships of the living and Neocenozoic American "opossum-like" marsupials (suborder Didelphimorphia), with comments on the classification of these and of the Cretaceous and Paleogene New World and European metatherians. In: Possums and opossums: studies in evolution (Ed. Archer, M.), vol. 1, pp. 1-89. Sydney: Surrey Beatty and Sons.

RIDGWAY, R. 1912. Color standards and color nomenclature. Washington, DC: Author, 43 pp.

Ronquist, F. \& HUELSENBECK, J.P. 2003. MRBAYES 3: Bayesian phylogenetic inference under mixed models. Bioinformatics 19(12):1572-1574.

Solari, S. 2003. Diversity and distribution of Thylamys (Didelphidae) in South America, with emphasis on species from the western side of the Andes. In: Predators with pouches - the biology of carnivorous marsupials (Jones, M., Dickman, C. \& Archer, M. eds.), pp. 82-101. CSIRO Publishing, Melbourne.

StatSoft, Inc. 2001. Statistica for Windows: computer program manual. StatSoft, Inc. Tulsa, Oklahoma.

Steiner, C., Tilak, M., Douzery, E.J.P. \& Catzeflis, F.M. 2005. New DNA data from a transthyretin nuclear intron suggest an Oligocene to Miocene diversification of living South American opossums (Marsupialia: Didelphidae). Molecular Phylogenetics and Evolution 35(2):363-379.

Swofford, D.L. 2000. PAUP*. Phylogenetic Analysis using Parsimony (*and other methods). Sinauer Associates, Sunderland, Massachusetts.

Tamura, K., Dudley, J., Nei, M. \& Kumar, S. 2007. MEGA 4: Molecular Evolutionary Genetics Analysis (MEGA) software version 4.0. Molecular Biology and Evolution 24(8):1596-1599.

TATE, G.H.H. 1933. A systematic revision of the marsupial genus Marmosa, with a discussion of the adaptive radiation of the murine opossums. Bulletin of the American Museum of Natural History 66:1-250.

Thomas, O. 1894. On Micoureus griseus, Desm., with description of a new genus and species of Didelphidae. Annals and Magazine of Natural History. 6(14):184-188.

Thomas, O. 1896. On new small mammals from the Neotropical Region. Annals and Magazine of Natural History 6(18):301-314.

Thomas, O. 1902. On Marmosa marmota and elegans, with descriptions of new subspecies of the latter. Annals and Magazine of Natural History. $7(10): 158-162$

Thomas, O. 1912. Three small mammals from South America. Annals and Magazine of Natural History 8(9):408-410.

Thomas, O. 1921. Three new species of Marmosa with note on Didelphys waterhousei Tomes. Annals and Magazine of Natural History 9(7):519-523.

Thompson, J.D., Gibson, T.J., Plewniak, F., Jeanmougin, F. \& Higgins, D.G., 1997. The CLUSTAL X 
windows interface: flexible strategies for multiple sequence alignment aided by quality analysis tools. Nucleic Acid Research 25(24):4876.

TriBe, C.J. 1990. Dental age classes in Marmosa incana and other didelphoids. Journal of Mammalogy 71(4): 566-569.

Voss R.S., JANSA S.A. 2003. Phylogenetic studies on didelphid marsupials II. Non molecular data and new IRBP sequences: separate and combined analyses of didelphine relationships with denser taxon sampling. Bulletin of the American Museum of Natural History 276:1-82.

Voss, R.S., TARIFA, T. \&YenSEN, E. 2004a. An introduction to Marmosops (Marsupialia, Didelphidae), with the description of new species from Bolivia and notes on the taxonomy and distribution of the Bolivian forms. American Museum Novitates 3466:1-40.

Voss, R.S., Gardner, A.L. \& Jansa, S.A. 2004b. On the relationships of "Marmosa" formosa Shamel 1930 (Marsupialia: Didelphidae), a phylogenetic puzzle from the Chaco of Northern Argentina. American Museum Novitates 3442:1-18.

Voss, R.S., Lunde, D.P. \& JANSA, S.A. 2005. On the contents of Gracilinanus Gardner and Creighton 1989, with the description of a previously unrecognized clade of small didelphid marsupials. American Museum Novitates 3482:1-34.

Voss, R.S. \& JANSA, S.A. 2009. Phylogenetic relationships and classification of didelphid marsupials, an extant radiation of New World metatherian mammals. Bulletin of the American Museum of Natural History 322:1-177.

Voss, R.S, Myers, P., Catzeflis, F., Carmignotto, A.P. \& Barreiro, J. In press. The six opossums of Félix de Azara: identification, taxonomic history, neotype designations, and nomenclatural recommendations.

\section{Appendix 1}

Specimens of Thylamys examined in this study. Acronyms for institutions are as follows. Argentina: Buenos Aires: Museo Argentino de Ciencias Naturales "Bernardino Rivadavia" (MACN); Museo de La Plata (MLP); Colección Elio Massoia (CEM); Chubut, Colección de Mamíferos del Centro Nacional Patagónico (CNP); Tucumán, Colección Mamíferos Lillo (CML); UK: Natural History Museum (BM); USA: Albuquerque: MSB (Museum of Southwestern Biology); Chicago: Field Museum of Natural History (FMNH); Connecticut: Connecticut State Museum of Natural History (UCON); Michigan, Ann Arbor: University of Michigan, Museum of Zoology (UMMZ); Texas: University of Texas Tech (TTU);
Washington: National Museum of Natural History, Smithsonian Institution (NMHN). An asterisk indicates specimens sequenced in this study. Thylamys citellus (15): Argentina: Corrientes Province: 1.- Goya, (-29.145458 S, -59.268165 W), BM 98. 8. 19. 9 [skin and skull photographs of the holotype]; 2.- Estancia Coropa (ca. -29.145458 S, -59.268165 $\left.{ }^{\circ} \mathrm{W}\right)$, BM 94.6.30.1 [skin and skull photographs]; 3.- Curuzú Cuatiá (-29.793156 S, -58.049323 W), MACN 22459; Entre Ríos Province: 4.- Estancia Santa Ana de Carpinchori $\left(-30.68333^{\circ} \mathrm{S},-58.78333^{\circ} \mathrm{W}\right), \mathrm{CNP} 1920^{*}$ (GQ911595); 5.- Margen oriental del Arroyo El Gato, confluencia con el arroyo Finca de Palo $\left(-30.719215^{\circ} \mathrm{S},-59.003015^{\circ} \mathrm{W}\right), \mathrm{CEM} \mathrm{s} / \mathrm{n}$; 6.La Paz $\left(-30.761916^{\circ}\right.$ S, $\left.-59.644012^{\circ} \mathrm{W}\right)$, B.M. 23.12.12.16 [skin and skull photograph]; 7.- Villa Federal $\left(-30.949430^{\circ} \mathrm{S}, 58.783125^{\circ} \mathrm{W}\right), \mathrm{MACN}$ 23532, 23533, MLP 27.IX.43.1; 8.- La Picada a $20 \mathrm{~km}$ de Paraná $\left(-31.733426^{\circ} \mathrm{S},-60.299893^{\circ} \mathrm{W}\right)$, MLP 3.VIII.99.13; 9.- Parque Nacional El Palmar $\left(-31.881223^{\circ} \mathrm{S}, 58.255093^{\circ} \mathrm{W}\right), \mathrm{MACN} 23459^{*}$ (GQ911594), MACN 23460* (GQ911594); 10.Pronunciamiento $\left(-32.34525^{\circ} \mathrm{S},-58.442986 \mathrm{~W}\right)$, MACN 16262, 16266; 11.- Río Gualeguaychú $\left(-32.606654^{\circ} \mathrm{S},-58.522164^{\circ} \mathrm{W}\right)$, MACN 23531.

Thylamys macrurus (1): Paraguay: Concepción: 7 km NE Concepción (MSB 70700);

Thylamys pallidior (11) Argentina: Jujuy: $8.2 \mathrm{~km}$ S Sey (-23.991326 $\left.{ }^{\circ} \mathrm{S},-66.565880^{\circ} \mathrm{W}\right)$, MACN 22546, 22547; Mendoza: Las Heras (-32.849330 S, -68.815253 W), MACN 22458, 22467, 22470; Neuquén: Catán Lill, Las Coloradas (-39.550870 S, -70.583665 $\left.{ }^{\circ} \mathrm{W}\right), \mathrm{MACN} 13495,13543,13837$; Salta: $1.8 \mathrm{~km}$ W Barrancas, along Río de Los Burros (-25.78942 $\left.1^{\circ} \mathrm{S},-66.460577^{\circ} \mathrm{W}\right)$, MACN 22548; San Luis: Quebrada de López, San Francisco del Monte de Oro $\left(-32.599162^{\circ} \mathrm{S},-66.132143^{\circ} \mathrm{W}\right)$, CML 3197; 1 km N Paso del Rey, Arroyo Cañada Honda $\left(-32.940945^{\circ} \mathrm{S},-66.000005^{\circ} \mathrm{W}\right), \mathrm{CML}$ 3194.

Thylamys pulchellus (16) Argentina: Chaco: 12.Almirante Brown $\left(-26.515137^{\circ} \mathrm{S},-61.167918^{\circ}\right.$ W), CML 3496; 13.- Avia Terai (-26.687611 ${ }^{\circ}$ S, $\left.-60.728215^{\circ} \mathrm{W}\right)$, BM 34.11.4.184; Santiago del Estero Province: 14.- Copo, $15 \mathrm{~km}$ E Picada de Olmos (ca. $-26.012009^{\circ} \mathrm{S},-62.253686^{\circ} \mathrm{W}$ ) CML 2081, 2082; 15.- Los Robles (-28.047299 S, -63.993560 W), MLP 21.X.35.32 [Holotype]; 16.- Guayasán $\left(-28.006645^{\circ} \mathrm{S},-64.817488^{\circ} \mathrm{W}\right)$, CML 3198; 17.- Virgen del Valle picnic area 
on Highway 64 between Santa Catalina and La Puerta Chiquita $\left(-28.135971^{\circ} \mathrm{S},-64.812805^{\circ} \mathrm{W}\right)$, CML 3198; 18.- San Antonio (-28.618313 ${ }^{\circ} \mathrm{S}$, $\left.-63.166943^{\circ} \mathrm{W}\right), \mathrm{MACN} 17278,17279 ; 19 .-$ Lago Muyo (-28.703170 $\left.\mathrm{S},-62.833059^{\circ} \mathrm{W}\right), \mathrm{CML}$ 1033, 1034; 20.- Anta, Campo Grande, Finca Los Colorados $\left(-24.616667^{\circ} \mathrm{S},-63.333333^{\circ} \mathrm{W}\right), \mathrm{CML}$ 3059, 5181, 5182, 5183, 5203.

Thylamys pusillus (55) Argentina: Formosa Province: 21.- Parque Nacional Río Pilcomayo, Puesto Quebrachal (ca. -25.095177 $\mathrm{S},-58.153845^{\circ}$ W), MACN 20730; 22.- Laguna Blanca (-25.170395 S, -58.129482 $\left.{ }^{\circ} \mathrm{W}\right), \mathrm{MACN} 20779 ; 2^{23}$ - Estancia Guaycolec $\left(-25.982889^{\circ} \mathrm{S},-58.167556^{\circ} \mathrm{W}\right)$, MACN 22469; 24.- El Bagual (-26.307822 ${ }^{\circ} \mathrm{S}$, -58.801345 ${ }^{\circ}$, CNP 600, 666, 670, 678, 684; Paraguay: 25.- Alto Paraguay: Palmar de Las Islas $\left(-19.633333^{\circ} \mathrm{S},-60.616667^{\circ} \mathrm{W}\right)$, TTU 65463; 26.- Fortín Pikyrenda $\left(-20.09^{\circ} \mathrm{S},-61.790556^{\circ} \mathrm{W}\right)$, TTU 65612, 65592; 27.- Puesto Militar Gabino Mendoza $\left(-20.057222^{\circ} \mathrm{S},-61.851111^{\circ} \mathrm{W}\right)$, TTU 65635,65649 ; 28.- Cerro León $\left(-20.440417^{\circ} \mathrm{S}\right.$, $\left.-60.321944^{\circ} \mathrm{W}\right)$, TTU 60463; 41.- 28 km N, 50 $\mathrm{km} \mathrm{W}$ of Mayor Pablo Lagerenza $\left(-19.667072^{\circ} \mathrm{S}\right.$, $\left.-61.267556^{\circ} \mathrm{W}\right), \mathrm{UCON} 19181,19182$; Boquerón: 29.- Dr. Pedro P. Peña (-22.450000 S, $-62.350000^{\circ}$ W), UCON 19198, NMNH 390027, 390028, 390029, 390030, 390031, 390032, 390033; 30.Fortin Teniente Gabino Mendoza $\left(-20.069800^{\circ} \mathrm{S}\right.$, $\left.-61.886300^{\circ} \mathrm{W}\right)$, TTU 65797; 31.- Trans-Chaco Highway km 655 (-21.098900 S, -61.615560
W), UCON 17056; 32.- Parque Nacional Teniente Agripino Enciso $\left(-21.135833^{\circ} \mathrm{S},-61.521944^{\circ}\right.$ W), TTU 66463, 66468, 66469, 66476, 65104, 65215, NMNH 555660; 33.- Estancia Iparoma, Filadelfia, $19 \mathrm{~km} \mathrm{~N}\left(-22.178420^{\circ} \mathrm{S},-60.033333^{\circ}\right.$ W), UCON 19207, 19212, 19216, 19220, 19233; 34.- Experimental Farm, $11 \mathrm{~km}$ NE Filadelfia: $\left(-22.283890^{\circ} \mathrm{S},-59.982220^{\circ} \mathrm{W}\right)$, FMNH 164095 , 164096; 35.-Estancia Toledo, $35 \mathrm{~km}$ W Filadelfia $\left(-22.350000^{\circ} \mathrm{S},-60.373080^{\circ} \mathrm{W}\right)$, FMNH 164097 ; 36.- Estancia "43" (-22.433333 ${ }^{\circ} \mathrm{S},-62.316667^{\circ}$ W), TTU 60217; 37.- Guachalla, Rio Pilcomayo $\left(-22.45^{\circ} \mathrm{S},-62.33333^{\circ} \mathrm{W}\right)$, FMNH 54369; 38.- Colonia Mennonita, Orloff $\left(-22.500000^{\circ}\right.$ S, $\left.-60.000000^{\circ} \mathrm{W}\right)$, FMNH 63862; 39.- Fortin Teniente Pratt-Gill A. F. Base, 11 km NW $\left(-22.612760^{\circ} \mathrm{S},-61.625690^{\circ} \mathrm{W}\right)$, UCON 19173 ; 41.- Estancia Pirazal (-23.366667 ${ }^{\circ} \mathrm{S},-59.766667^{\circ}$ W), UCON 19138, 19225; Nueva Asunción: 41.- Trans-chaco Highway km 588, $19 \mathrm{~km}$ WSW (-21.347121 $\left.{ }^{\circ} \mathrm{S},-61.916196^{\circ} \mathrm{W}\right)$, UMMZ TWN227, TWN275, TWN276, TWN434; 43.$\mathrm{km} 588$ on Trans-Chaco Highway $\left(-21.534333^{\circ}\right.$ $\left.\mathrm{S},-61.263813^{\circ} \mathrm{W}\right)$, UCON 18862; 44.- Copagro, San Francisco del Chaco Boreal (-21.550000 S, -61.250000 W), UCON18868; Presidente Hayes: 45.- Estancia Experimental Chaco Central, $2 \mathrm{~km}$ W Cruce Pioneros $\left(-22.678330^{\circ} \mathrm{S},-59.772500^{\circ}\right.$ W), FMNH 164088; 46.- Trans-Chaco Highway $\mathrm{km} 412$, Cruce Pioneros, $2 \mathrm{~km} \mathrm{~W}\left(-22.678333^{\circ} \mathrm{S}\right.$, $\left.-59.939170^{\circ} \mathrm{W}\right)$, FMNH 157155. 